\title{
Bosnia and Herzegovina: 2007 Article IV Consultation-Staff Report; Public Information Notice on the Executive Board Discussion; and Statement by the Executive Director for Bosnia and Herzegovina
}

Under Article IV of the IMF's Articles of Agreement, the IMF holds bilateral discussions with members, usually every year. In the context of the 2007 Article IV consultation with Bosnia and Herzegovina, the following documents have been released and are included in this package:

- The staff report for the 2007 Article IV consultation, prepared by a staff team of the IMF, following discussions that ended on May 22, 2007, with the officials of Bosnia and Herzegovina on economic developments and policies. Based on information available at the time of these discussions, the staff report was completed on June 28, 2007. The views expressed in the staff report are those of the staff team and do not necessarily reflect the views of the Executive Board of the IMF.

- $\quad$ A Public Information Notice (PIN) summarizing the views of the Executive Board as expressed during its July 16, 2007 discussion of the staff report that concluded the Article IV consultation.

- $\quad$ A statement by the Executive Director for Bosnia and Herzegovina.

The document listed below has been or will be separately released.

Selected Issues Paper

The policy of publication of staff reports and other documents allows for the deletion of market-sensitive information.

To assist the IMF in evaluating the publication policy, reader comments are invited and may be sent by e-mail to publicationpolicy@imf.org.

\author{
Copies of this report are available to the public from \\ International Monetary Fund • Publication Services \\ $70019^{\text {th }}$ Street, N.W. • Washington, D.C. 20431 \\ Telephone: (202) 623-7430 • Telefax: (202) 623-7201 \\ E-mail: publications@imf.org • Internet: http://www.imf.org
}

Price: $\$ 18.00$ a copy

\section{International Monetary Fund Washington, D.C.}





\title{
INTERNATIONAL MONETARY FUND
}

\author{
BOSNIA AND HERZEGOVINA
}

\section{Staff Report for the 2007 Article IV Consultation}

\author{
Prepared by the Staff Representatives for the 2007 Consultation with \\ Bosnia and Herzegovina
}

Approved by Juha Kähkönen and Scott Brown

June 28, 2007

\section{Executive Summary}

Background and outlook: Strong growth and low inflation reflect the benign international environment, the effects of past reforms in certain sectors, and the currency board. The introduction of VAT yielded high — but partly temporary — revenues leading to a large fiscal surplus in 2006. Strong export growth and subdued imports reduced the current account deficit to $11 \frac{1}{2}$ percent of GDP in 2006 (possibly 5-7 percent of GDP after correcting for underreporting of current receipts).

Although balance of payments data weaknesses hamper an accurate assessment, the real exchange rate does not appear to be misaligned and recent export trends are reassuring. Bosnia \& Herzegovina's complex constitutional arrangements and ethnic divisions weaken incentives to cooperate and policies drifted last year. Unless this drift is reversed, the lapsing of one-off VAT revenue and last year's pre-election spending hikes would generate a fiscal deficit in 2007; and over the medium term, growth could lose steam and net foreign liabilities could rise further.

Authorities' policies: All three governments indicated that they share the goals of maintaining a prudent fiscal position and preserving competitiveness through structural reforms, creating a single economic space, and ensuring financial stability. But these goals are not always translated into coherent policy plans: there is no medium-term framework for the government as a whole, fiscal policy coordination is weak, and the reform momentum is slow.

Staff recommendations: Minimize the swing in the fiscal position in 2007 and aim at a general government balance over the medium term. Use large privatization receipts expected in 2007-08 to finance pension reform and not for current spending. Private sector involvement in infrastructure would be appropriate but only if a strong institutional framework is in place. Improve fiscal policy coordination through a strong Fiscal Council law, though ultimately the political will to cooperate is paramount. Harmonize direct taxes, liberalize the labor market, and ensure the portability of social benefits to create a single economic space. Improve credit risk management further, unify bank supervision, and close gaps in nonbank oversight.

Bosnia \& Herzegovina has not accepted the obligations under Art. VIII, Sections 2, 3 and 4 but maintains restrictions on the transferability of balances and interest accrued on frozen foreign currency deposits. Staff does not recommend approval of these restrictions. 
Executive Summary ....... 1

I. Recent Developments and Outlook ......................................................... 3

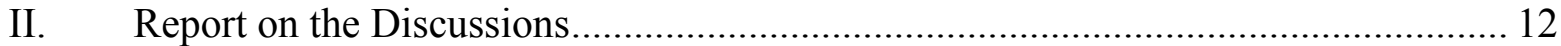

A. Fiscal Policy ............................................................................................. 14

B. Improving Policy Coordination and Creating a Single Economic Space ............. 16

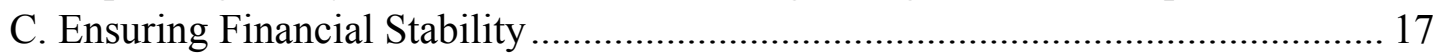

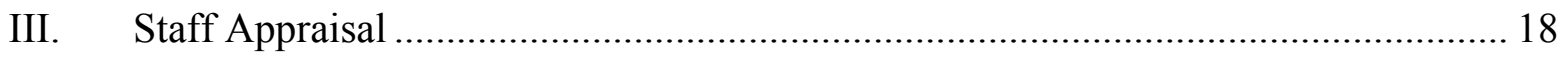

\section{Text Boxes}

1. Government Debt Laws ............................................................................. 8

2. Implementation of Fund Policy Recommendations............................................. 13

Figures

1. Recent Economic Developments ................................................................ 4

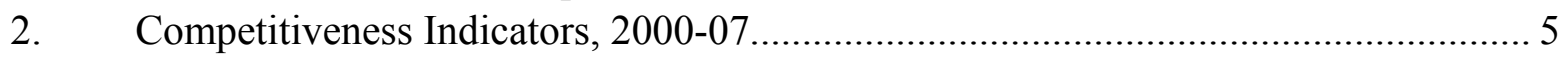

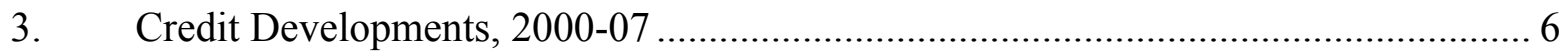

4. Financial System Indicators ...................................................................... 7

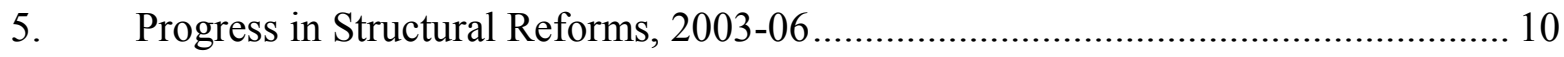

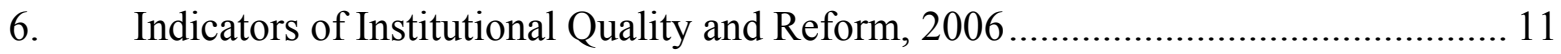

Tables

1. Selected Economic Indicators, 2003-07 ...................................................... 21

2. Balance of Payments, 2003-12 …......................................................................... 22

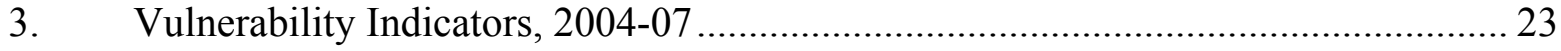

4. General Government, 2003-07............................................................................... 24

5. Elements of General Government, 2003-07 ….................................................. 25

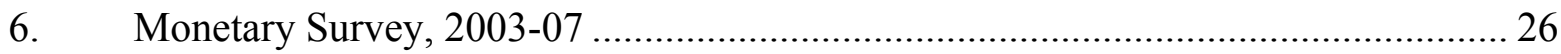

7. Monetary Authorities' Balance Sheet, 2003-07..................................................... 27

8. Survey of Domestic Money Banks, 2003-07 ....................................................... 28

9. Staff Illustrative Medium-Term Framework, 2004-12 ......................................... 29

Attachment

I. Debt Sustainability Analysis.......................................................................... 30

Annexes

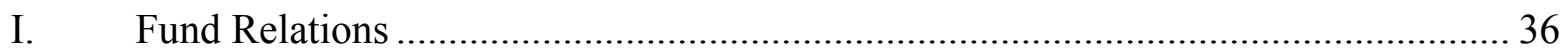

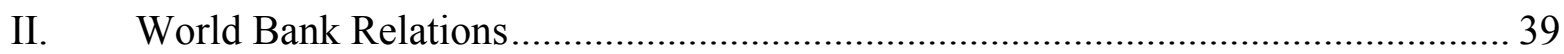

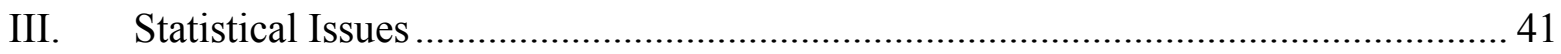




\section{RECENT DEVELOPMENTS AND OUTLOOK}

1. Bosnia \& Herzegovina labors under a complex and fragmented political system. The Dayton Peace Agreement that ended the war in 1995 created two largely autonomous Entities (the Republika Srpska (RS) and the Croat-Bosniak Federation of Bosnia \& Herzegovina (Federation), itself divided into ten largely ethnic cantons), which exercise most economic power; and a State government with a very limited mandate. This structure has entrenched ethnic divisions, as highlighted by last October's elections; causes fragmentation and duplication of many domestic policy functions; and weakens incentives to cooperate. The Office of the UN High Representative (HR), with extensive powers to impose or overrule legislation and dismiss elected officials, has so far held the system together and gradually expanded the mandate of the State. Recognizing the need for greater local ownership, the HR has recently curbed the use of these powers, and his office is to be closed in 2008. But a modest first attempt at constitutional reform failed in 2006; key measures, like police reform - a condition for signing the Stabilization \& Association Agreement with the EU—are stalled; and policy coordination between Entities and State is weak.

\section{The economy is nevertheless enjoying its fourth consecutive year of stable} growth underpinned by the currency board. Export growth of 29 percent on the back of productivity gains, export price increases, and improvements in reporting following the introduction of the VAT, combined with robust domestic demand, pushed real GDP up 6 percent last year (Figure 1). The export expansion slowed this year (the improvement in reporting was one-off) but was still 24 percent in the first four months compared to the same period last year. The currency board anchored prices: headline inflation, reflecting the VAT effect and administered price hikes, averaged 7 percent last year but declined to $1 \frac{1}{2}$ percent in early 2007. The recorded current account deficit was almost halved last year to 11.5 percent of GDP reflecting the improvement in the trade gap; the "true" deficit was probably 5-7 percent of GDP as official statistics underestimate current inflows. Unit labor cost trends and other standard indicators suggest that competitiveness is favorable, while the recent gains in export market shares were broadly based and focused in key markets, as well as in sectors of growing global importance (Figure 2). Bank borrowing and other unidentified inflows pushed official reserves to $€ 2.9$ billion (51/4 months of imports) at end-April 2007.

\section{The pace of financial deepening, a key contributor to growth, is consistent with} regional trends, although supervision has weaknesses. After an initial surge, steady private sector credit growth of about 25 percent annually has contributed to a gradual increase in the credit-to-GDP ratio. The pace of financial deepening is in line with trends in Central and Southeastern Europe (Figure 3). On the supply side, credit expansion is stimulated by competition and consolidation in the banking sector, which is dominated by foreign banks, and financed largely by lending from these banks to their local affiliates (Figure 4; for an in-depth analysis, see accompanying Selected Issues paper, Chapter VI). 
Figure 1. Bosnia and Herzegovina: Recent Economic Developments

Sustained growth during the recent years...

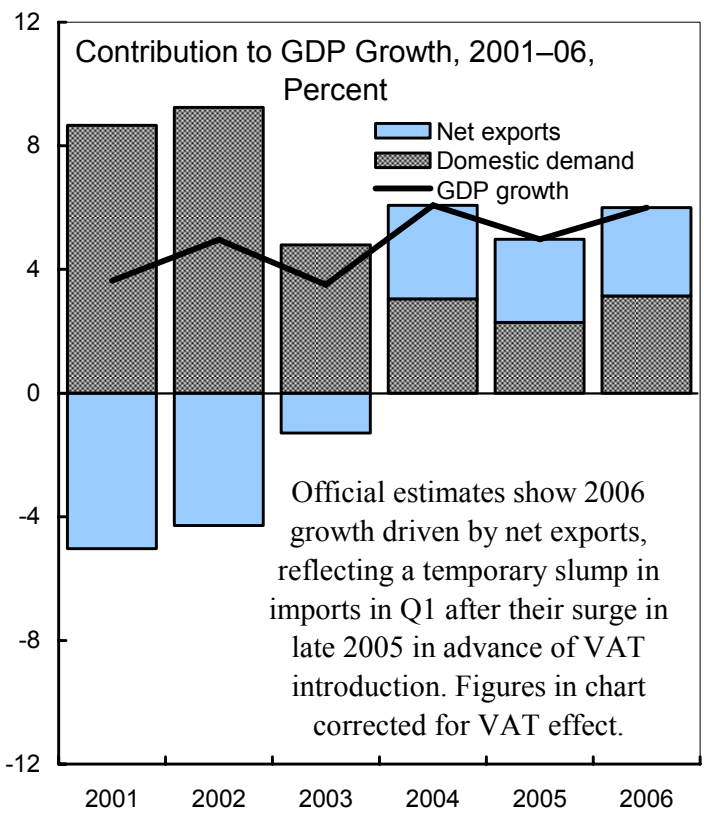

...was underpinned by rapid industrial production growth...

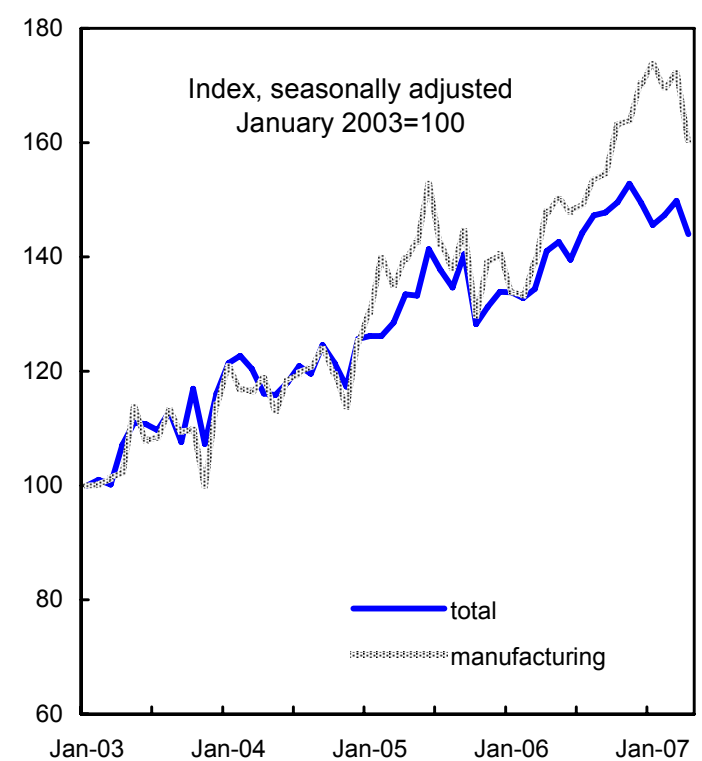

...with inflation returning to low levels after a VAT-related surge...

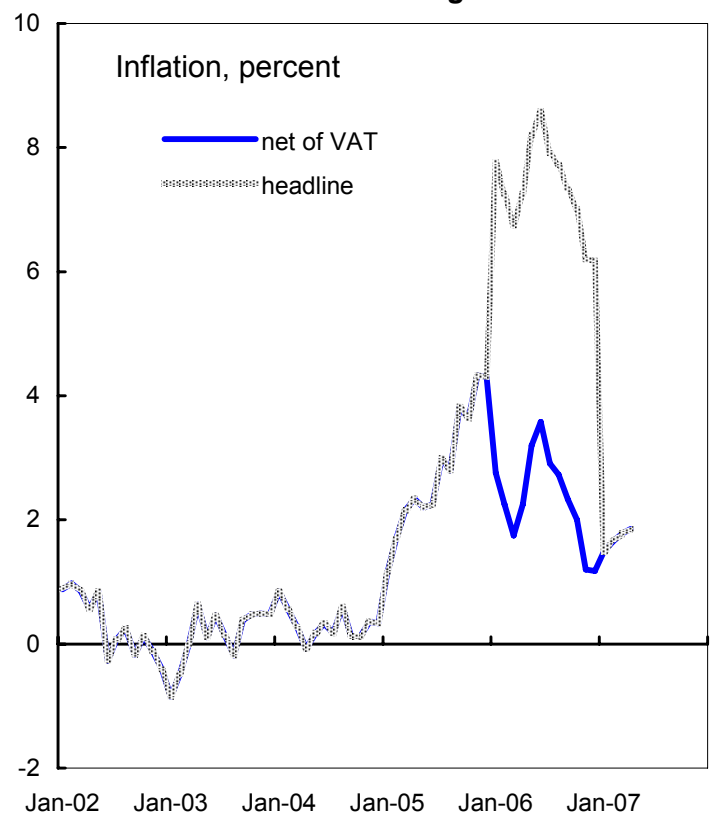

...and strengthening export performance.

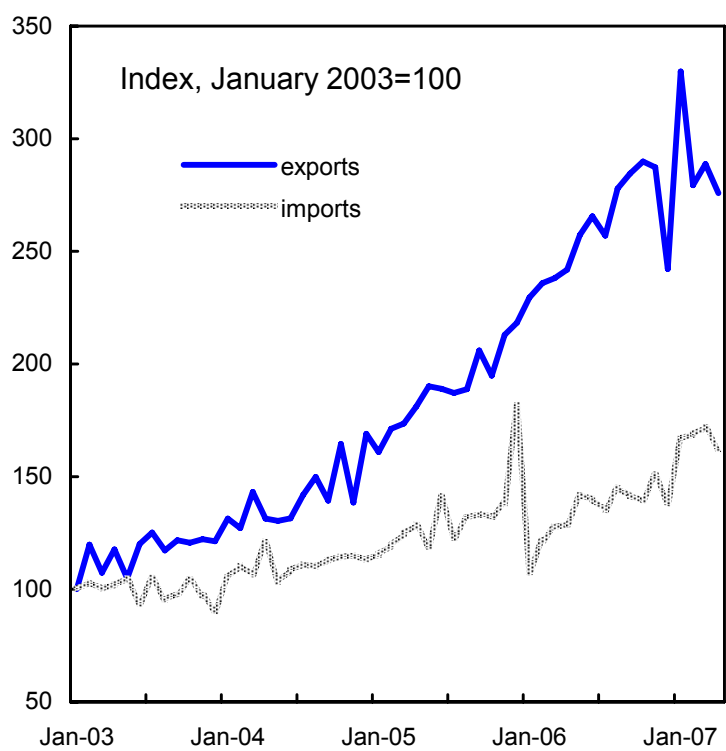

Sources: Bosnian authorities; and Fund staff calculations. 
Figure 2. Bosnia and Herzegovina: Competitiveness Indicators, 2000-07

Favorable external competitiveness, indicated by REER...

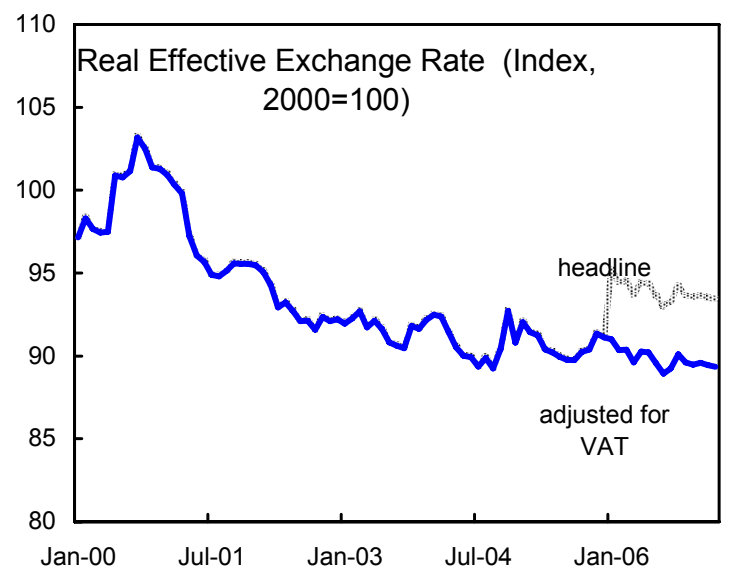

...and relative unit labor costs, ...

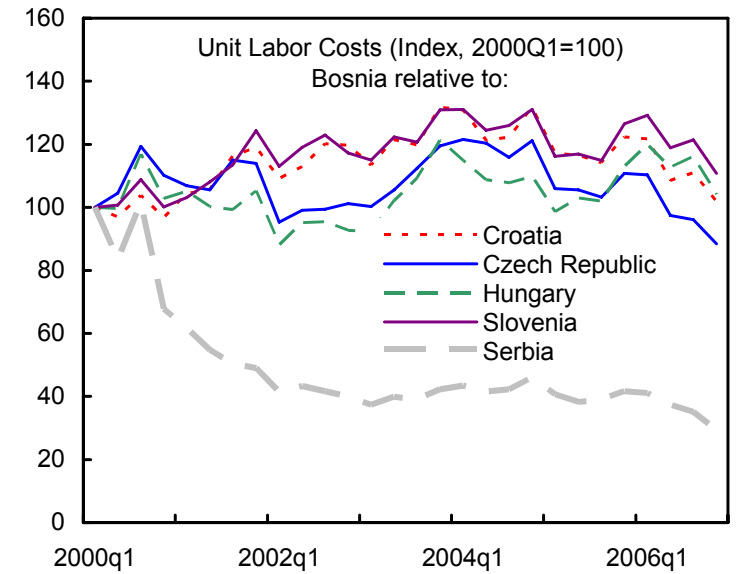

...underpins the broad-based gains in market share across sectors, particularly in those with relatively faster growth in global trade...

BiH Manufacturing Exports by Main Category, 2003-05

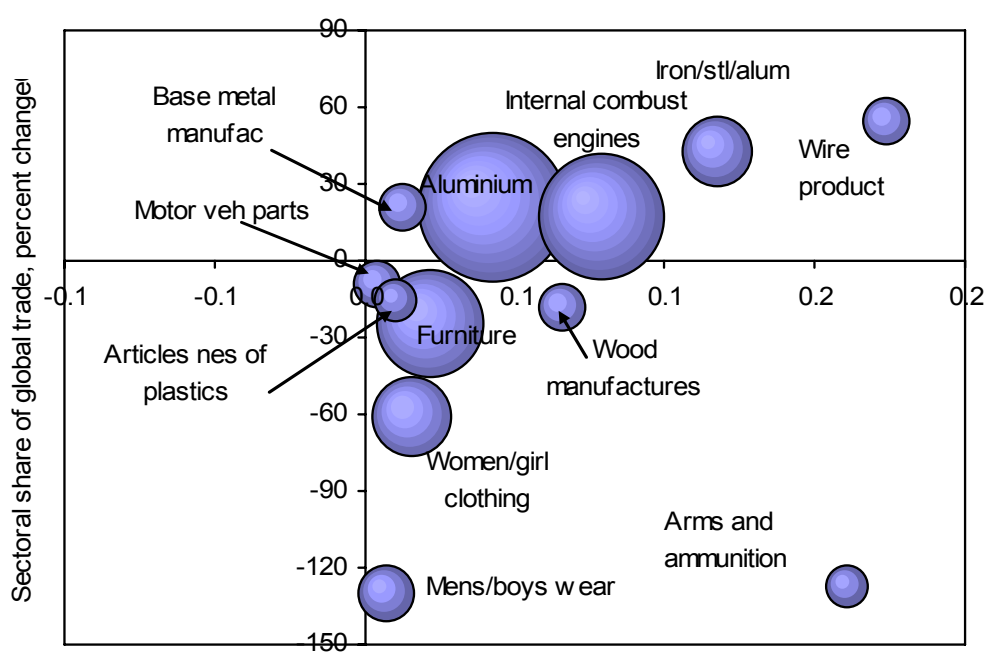

Bosnia \& Herzegovina's market share, percent change

...and helps explain rapid penetration in key export markets.

Bosnia \& Herzegovina's Market Shares in Selected Key Markets (in percent)

\begin{tabular}{lcccccccc}
\hline & \multicolumn{3}{c}{ Shares of imports from BiH in total imports from: } \\
& \multicolumn{3}{c}{ Eastern Europe } & & \multicolumn{3}{c}{ ex-Yugoslavia } \\
\cline { 2 - 4 } \cline { 7 - 9 } & 1995 & 2000 & 2005 & & 1995 & 2000 & 2005 \\
\hline USA & 0.10 & 0.10 & 0.20 & & 1.80 & 2.90 & 7.40 \\
Austria & 0.01 & 0.51 & 1.03 & & 0.06 & 3.38 & 6.93 \\
Germany & 0.04 & 0.24 & 0.39 & & 0.33 & 2.91 & 6.14 \\
Italy & 0.2 & 2.03 & 1.64 & & 0.68 & 8.74 & 8.81 \\
\hline
\end{tabular}

Sources: Bosnian authorities; Direction of Trade Statistics;; Comtrade; and Fund staff. calculations. 
Figure 3. Bosnia and Herzegovina: Credit Developments, 2000-07

The pace of credit expansion has been steady...

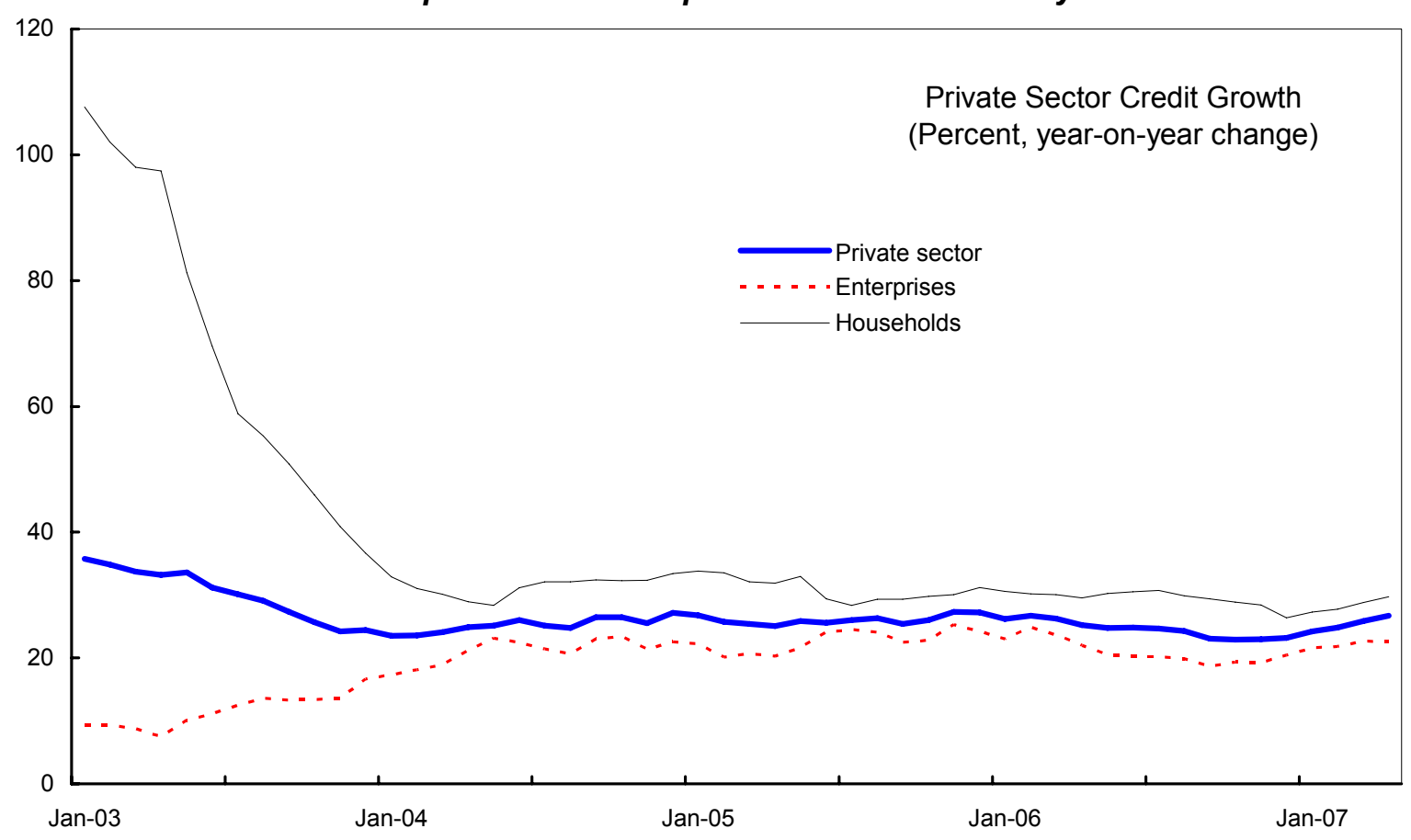

...and broadly in line with the regional experience.

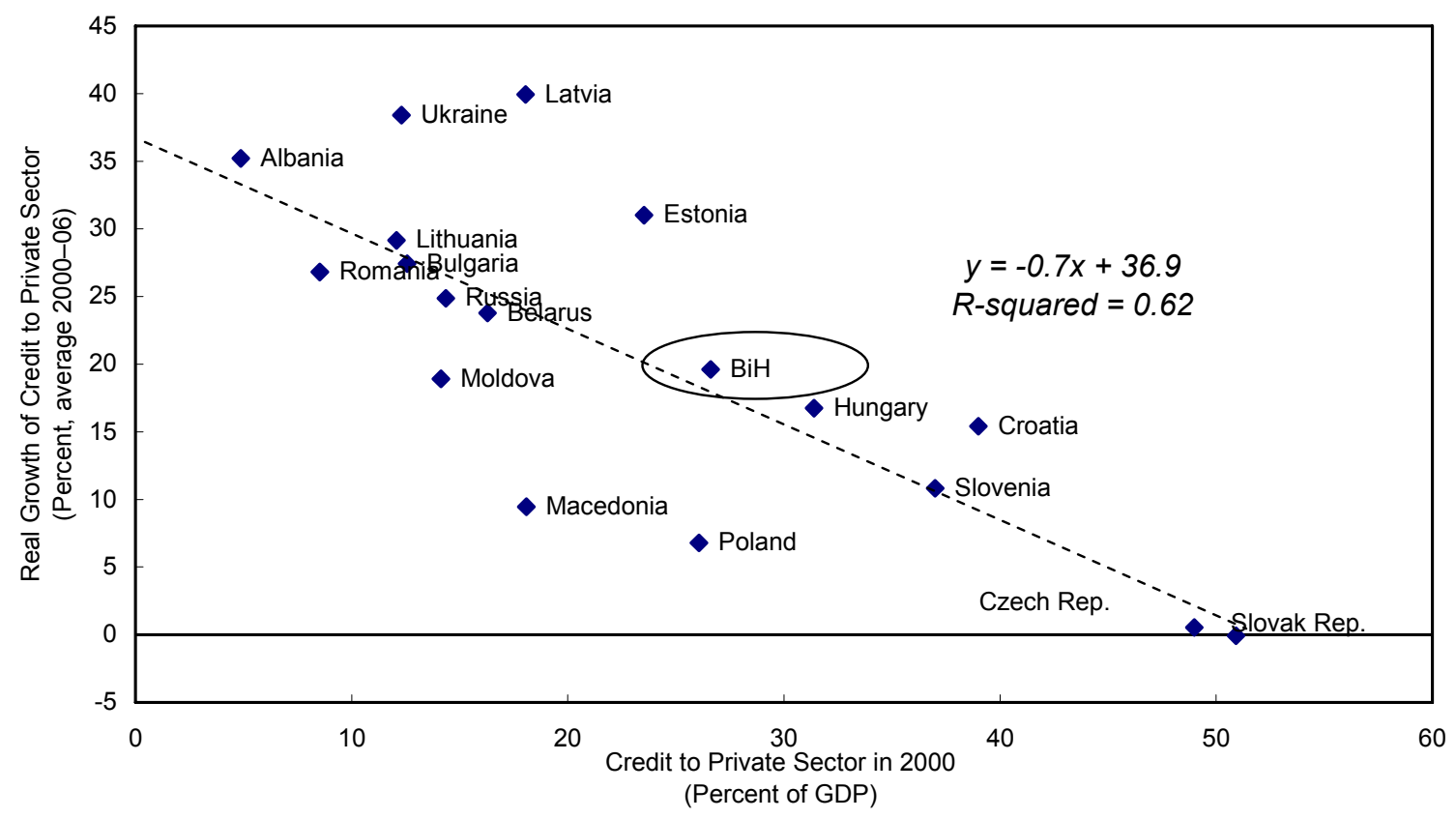

Sources: Bosnian authorities; and IMF staff calculations. 
Figure 4. Financial System Indicators

At the macro level, customer deposits and foreign debt are important sources of financing of credit growth.

Financing of Private Sector Credit Growth, 2001-06

\begin{tabular}{lc}
\hline & $\begin{array}{c}\text { Cumulative change in } \\
\text { percentage points of GDP }\end{array}$ \\
\hline Private sector credit & 24.8 \\
Assets & \\
Claims on non-central government & 0.1 \\
Net assets held with the central bank & 9.1 \\
& \\
Liabilities & \\
Net foreign liabilities & 8.1 \\
Net central government deposit & 2.1 \\
Non-central gov deposits & 2.0 \\
Private sector deposits & 18.9 \\
Other item, net & 2.9 \\
\hline
\end{tabular}

Banks rely on funding from abroad to finance long-term credits.

Bank Foreign Liabilities and Capital Inflows (In percent of GDP)

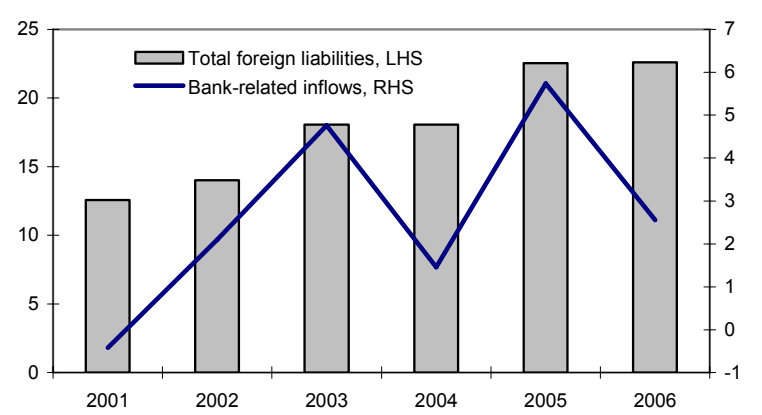

Rising excess reserves at the CBBH however shows banks' inability to intermediate short-term deposits

Reserves and Credit Flows, (In percent of GDP)

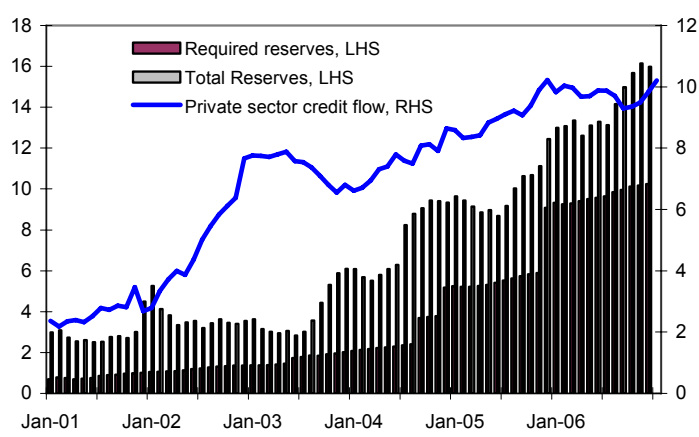

Capital inflows to finance credit growth account for a large share of the increase in international reserves

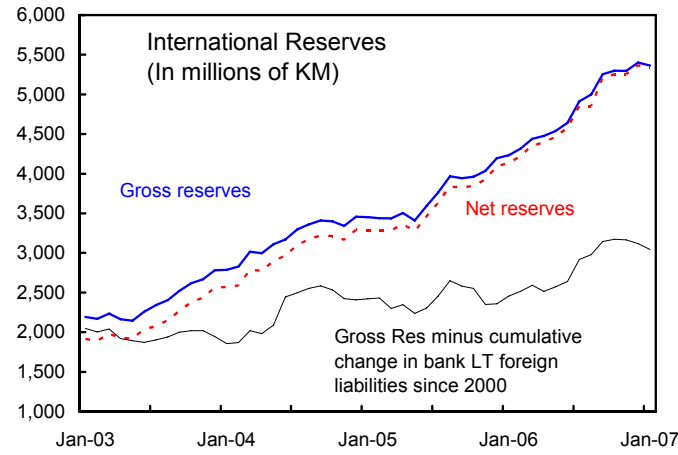

Banking System Soundness Indicators, 2001-06

(Percent)

\begin{tabular}{|c|c|c|c|c|c|c|}
\hline & 2001 & 2002 & 2003 & 2004 & 2005 & 2006 \\
\hline Regulatory capital to risk-weighted assets & 25.1 & 20.5 & 20.3 & 18.7 & 17.8 & 17.7 \\
\hline Nonperforming loans (NPL) to total loans & 17.9 & 11.0 & 8.4 & 6.1 & 5.3 & 4.0 \\
\hline Return on assets & -1.1 & -0.3 & 0.4 & 0.7 & 0.7 & 0.9 \\
\hline Return on equity & -3.5 & 2.5 & 3.4 & 5.8 & 6.2 & 8.5 \\
\hline
\end{tabular}


Although bank soundness indicators are good and improving, last year's FSAP identified a number of weaknesses in supervision, notably its fragmentation into two Entity-based agencies. While this has not been addressed, the inclusion of individuals in the credit registry in 2007—also an FSAP recommendation — was a key step toward better risk management. ${ }^{1}$

\section{Fiscal policy has thus far been prudent and public debt low, though the size of}

the government is large. Since 2004, the general government has been close to balance or in surplus. The VAT introduced on January 1, 2006 generated a surge of revenue, partly due to one-off factors (estimated at $1 \frac{1}{2}$ percent of GDP), while the share of expenditures was kept at its 2005 level. The general government thus recorded a surplus of 3 percent of GDP. At about 50 percent of GDP, the size of the government is large, reflecting inefficiencies and duplication of functions. At the same time, at 23 percent of GDP at end-2006, public debt is low. Even after the planned bond issuance to cover outstanding domestic claims against the government - which staff assumes will raise the debt-to-GDP ratio by some 25 percentage points over the next three years the debt will still be low in net present value terms, as most of it is concessional. The introduction of statutory borrowing limits for all levels of government was a major step toward fiscal discipline: though not yet binding, these ceilings could be helpful in limiting fiscal deficits in the future (Box 1).

\section{Box 1. Government Debt Laws}

Law on government borrowing, debt, and guarantees were adopted by the State in 2005 and the RS in 2007, and a similar draft law is pending approval in the Federation.

Borrowing limits. The state and RS laws limit borrowing by imposing ceilings on projected debt service (including amortization) at 18 percentage of previous year's revenue. In the RS, the limit also applies to municipalities, whose foreign borrowing requires a separate approval from the Finance ministry if projected debt service exceeds 10 percent of municipal revenue. The State limit will be subject to annual reviews after the first three years. The Federation draft law imposes the same debt service ceiling. Within this envelope, the cap for cantons is 5 percentage, and that for municipalities gradually rises from 3 to 10 percent.

Institutional framework. The State Finance ministry prepares a five-year State Debt Management Strategy in cooperation with a Debt Committee (an advisory body composed of representatives of the State and Entities, including Finance Ministers). A separate Debt committee in the Federation, composed of the Federal and cantonal Finance Ministers, coordinates borrowing and debt management in the Entity.

\section{This good overall picture reflects a benign external environment and the effects} of past economic reforms. Growth in Bosnia \& Herzegovina's trading partners was strong. World prices of metals - a key export- have risen 55 percent over 2005-06. Low world

\footnotetext{
${ }^{1}$ The FSSA was published as Report 06/403.
} 
interest rates facilitated the financing of the current account deficit. Although Bosnia \& Herzegovina generally lags behind the region in terms of structural reforms (Figures 5 and 6), certain reforms in specific sectors have had a sizeable impact: industrial production and exports of key products, such as steel and aluminium, benefited from foreign investment; the successful introduction and administration of the VAT led to the good fiscal outcome in 2006; last but not least, the process of financial deepening was spurred by the privatization and opening of domestic banks to foreign participation.

\section{The outlook for the rest of $\mathbf{2 0 0 7}$ is fair, but the effects of long-standing} weaknesses will start becoming evident. The momentum of growth is projected to continue, the international economic environment to remain favorable, and inflation to remain contained. In contrast to these positive trends:

- The governments' failure to resist spending pressures in the runup to last October's elections will, in the absence of corrective action, cause a sharp deterioration of the government balance. The one-off effects of the VAT will disappear while the bill for pre-election spending increases - most notably in the Federation - will come due this year. As a result, the general government could register a deficit of up to $1 \frac{1}{2}$ percent of GDP in 2007.

- $\quad$ This fiscal impulse, combined with higher private demand, will boost imports, as data for the first four months already show. As a result, the current account deficit is likely to widen somewhat in 2007. Large privatization receipts, however, will provide sufficient non debt-creating financing.

7. The medium-term baseline outlook is relatively stable but, under current policies, the risks would gradually increase. These risks are explored further in Chapters II-IV of the accompanying Selected Issues paper.

- $\quad$ Net exports will continue to provide stimulus reflecting strong partner demand and recent trends in market penetration, but growing export volumes would be partly offset by falling world metal prices (WEO) in the outer years. On the assumption of continued structural policy drift, the staff's baseline scenario (Table 9) assumes that growth would slowly lose steam, the private savings-investment gap would narrow only marginally, and the current account deficit would stay high. Although net foreign liabilities now are low, persistent current account deficits would eventually bring them to very high levels. 
Figure 5. Bosnia and Herzegovina: Progress in Structural Reforms, 2003-06

Bosnia \& Herzegovina still lags behind neighboring countries.. .

Bosnia \& Herzegovina and Selected Countries: EBRD Transition Indicator Scores, 2006

\begin{tabular}{|c|c|c|c|c|c|c|c|c|c|c|}
\hline & & \multicolumn{3}{|c|}{ Enterprises } & \multicolumn{3}{|c|}{ Markets and Trade } & \multicolumn{2}{|c|}{ Financial Institutions } & \multirow{2}{*}{$\begin{array}{c}\text { Infrastructure } \\
\text { Infrastructure } \\
\text { reform }\end{array}$} \\
\hline & $\begin{array}{l}\text { Private sector } \\
\text { share of GDP } \\
\text { EBRD midyear } \\
\text { estimate (\%) }\end{array}$ & $\begin{array}{l}\text { Large-scale } \\
\text { privatization }\end{array}$ & $\begin{array}{l}\text { Small-scale } \\
\text { privatization }\end{array}$ & $\begin{array}{l}\text { Governance \& } \\
\text { enterprise } \\
\text { restructuring }\end{array}$ & $\begin{array}{c}\text { Price } \\
\text { liberalization }\end{array}$ & $\begin{array}{l}\text { Trade \& foreign } \\
\text { exchange } \\
\text { system }\end{array}$ & $\begin{array}{c}\text { Competition } \\
\text { policy }\end{array}$ & $\begin{array}{l}\text { Banking reform } \\
\text { \& interest rate } \\
\text { liberalization }\end{array}$ & $\begin{array}{c}\text { Securities markets } \\
\text { \& nonbank } \\
\text { financial } \\
\text { institutions }\end{array}$ & \\
\hline $\mathrm{BiH}$ & 55 & 2.7 & 3.0 & 2.0 & 4.0 & 3.7 & 1.7 & 2.7 & 1.7 & 2.3 \\
\hline CE/Baltic 1/ & 76 & 3.8 & 4.3 & 3.4 & 4.3 & 4.3 & 3.2 & 3.8 & 3.3 & 3.2 \\
\hline SE Europe 2/ & 67 & 3.3 & 3.9 & 2.6 & 4.2 & 4.2 & 2.2 & 3.1 & 2.3 & 2.6 \\
\hline
\end{tabular}

Sources: EBRD Transition Report, 2006; and IMF staff calculations of (unweighted) regional averages.

1/ Eight new EU member states: Czech Republic, Estonia, Hungary, Latvia, Lithuania, Poland, Slovakia, and Slovenia.

2/ Southeastern Europe (excluding Bosnia and Herzegovina): Albania, Bulgaria, Croatia, FYR Macedonia, Montenegro, Romania, and Serbia.

... and the pace of structural reform has been slow.

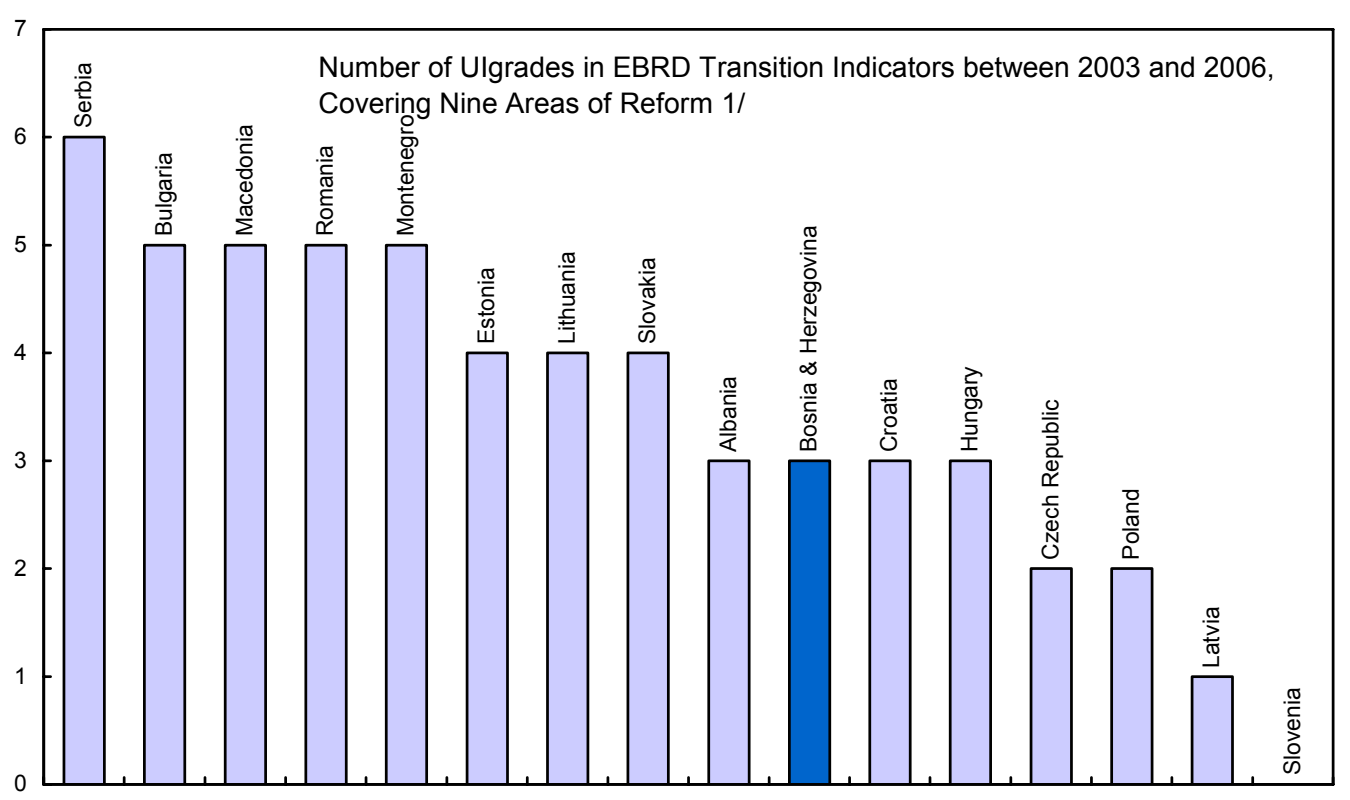

Sources: EBRD Transition Reports, 2003 and 2005; and IMF staff estimates of unweighted regional and category averages. Indicators range from 1 (no reform) to $4+$ (standards of an industrialized market economy).

1/ The nine areas are large-scale privatization; small-scale privatization; governance \& enterprise restructuring; price liberalization; trade \& foreign exchange system; competition policy; banking reform \& interest rate liberalization; securities markets \& nonbank financial institutions; and infrastructure reform. 
Figure 6. Indicators of Institutional Quality and Reform, 2006 (Rank, unless otherwise specified)
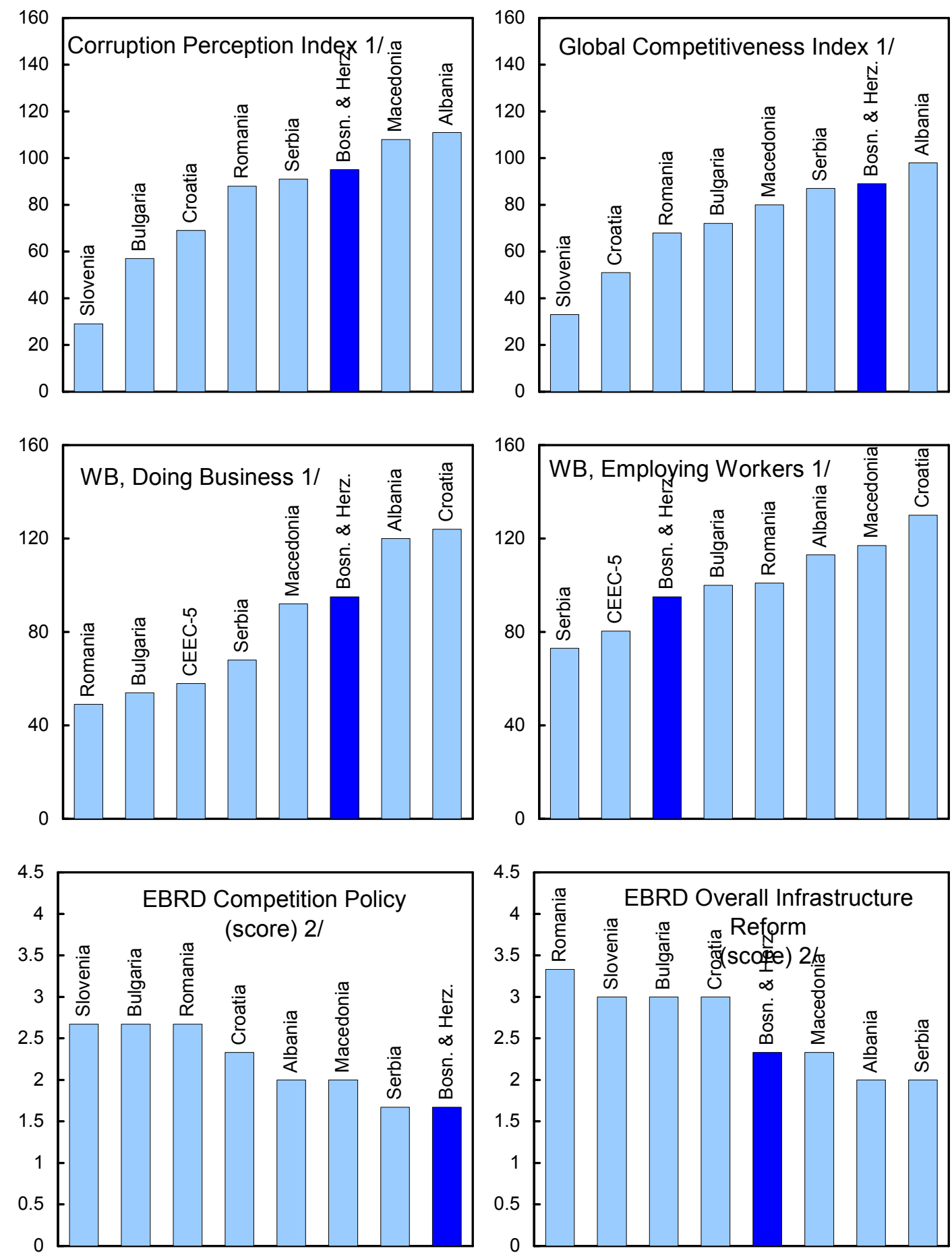

Sources: Transparency International; World Bank, Doing Business Database; World Economic Forum.

1/ Lower ranking means better environment. The corruption perception index relates to perceptions of the degree of corruption as seen by business people and country analysts. The global competitiveness index covers 125 countries. The World Bank indices cover 175 countries.

2. The EBRD maximum score is 4.33 , with maximum being best. 
- $\quad$ Economic growth would not make a significant dent in unemployment unless the Entity governments - under whose purview these policies fallimplement corporate restructuring and tax and labor market reforms.

Moreover, because labor mobility is limited, unemployment in depressed areas would stay high and the creation of a single labor market — and thus a single economic space-prove elusive.

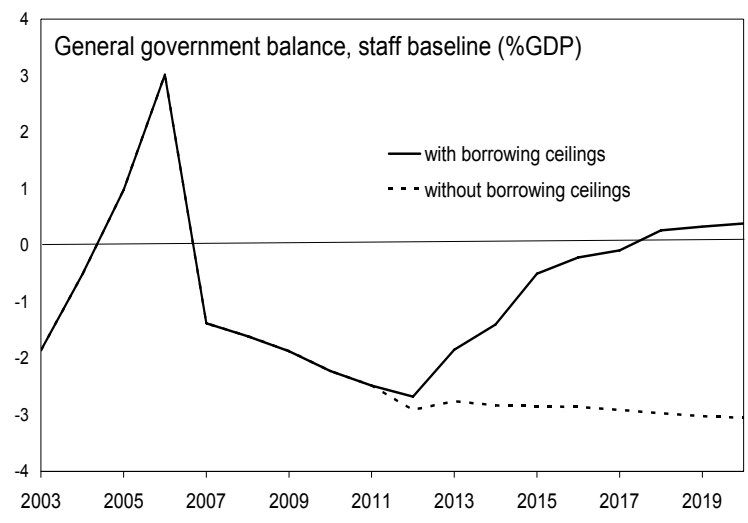

- Government revenues are projected to decline slowly, reflecting the loss of trade taxes as EU integration advances while, absent new measures, expenditures would remain high, leading to a gradual deterioration in the general government balance. Toward the end of the decade, when the statutory borrowing limits become binding, the adjustments required to comply would be significant. Absent a comprehensive medium-term fiscal strategy and effective policy coordination, however, it is not clear how these adjustments would be made.

- $\quad$ Financial sector indicators were reassuring and some steps have been made in response to the FSAP recommendations last year. However, remaining vulnerabilities in the system could, if left unaddressed, amplify the impact of other shocks.

\section{REPORT ON THE DISCUSSIONS}

8. There was consensus on the broad strategic economic objectives... The programs of the new governments emphasized private sector development; strengthening competitiveness to reduce the current account deficit and safeguard the currency board; creating jobs in the formal economy to make a dent in high unemployment; building a single economic space through tax harmonization; and preparing for EU membership.

\section{9. ...but the authorities took a different view of the medium-term outlook than}

staff. They considered that the recent improvement in the external position alleviated the concerns about external sustainability expressed by staff in last year's consultation and validated their more optimistic assessment. They stressed that the unchanged-policies assumption of the staff's baseline was unduly pessimistic: the new governments would accelerate the pace of reform, leading to more broad-based and sustainable growth. And they expected export performance to continue strengthening.

\section{Staff acknowledged that there was significant upside potential to its baseline} outlook if reforms accelerated, but pointed out that Bosnia \& Herzegovina's reform 
record was poor. Staff agreed that recent export trends were reassuring: if they persisted, the current account would continue to improve and net foreign liabilities could stabilize within a decade (see accompanying Selected Issues paper, Chapter II). But staff cautioned that first, these trends were recent; second, that this assessment was subject to larger-than-usual uncertainties due to data deficiencies; and, third, that it was conditional on prudent fiscal policies and an acceleration of structural reforms going forward. In this connection, the authorities' record in implementing the Fund's past policy advice was poor (Box 2), reflecting weak ownership, fragmented institutions, low administrative capacity and-last year-preoccupation with the elections. Staff noted that, with the exception of the latter, these factors were still present.

\section{Box 2. Implementation of Fund Policy Recommendations}

Since the last Fund arrangement expired, there have been three Article IV consultations (in 2004, 2005, and 2006) with broadly similar recommendations.

Fiscal policy. The general government generated surpluses in 2005 and 2006. However, the projected policy easing in 2007 would be inappropriate. Untargeted social transfers increased further in 2006 and there has been little progress in rationalizing government spending and reducing the tax burden on labor.

Fiscal coordination. The draft law on the Fiscal Council is yet to be adopted.

Financial sector. The authorities have responded positively to the 2006 FSAP. A financial sector surveillance unit has been established within the Central Bank of Bosnia \& Herzegovina (CBBH), but the decision on unifying banking supervision remains hostage to domestic politics.

Structural reform. Progress in macro-critical reforms - corporate restructuring, private sector development, improving the business climate, labor market liberalization - has been patchy and unequal: progress has been made in the RS but very little in the Federation.

\section{Against this background, discussions focused on (i) policies to ensure} macroeconomic and financial stability; and (ii) steps to improve coordination and create a single economic space. Staff argued that the combination of a benign external economic environment, strong growth momentum, and a fresh mandate from the electorate to the new governments provided a good opportunity to address these challenges. The authorities agreed, and stressed their intention to focus their energies on the economy. They also agreed that past Fund advice on corporate restructuring and private sector development was still relevant, although these topics were not a major focus of this year's consultation discussions. There is a high probability, however, that fundamental constitutional and political issues will continue to dominate the debate in the near term. 


\section{Staff stressed the need to improve the quality of statistics, which was not}

adequate for effective surveillance. Improvements in national accounts and price statistics, under preparation with Fund assistance, needed to be implemented as soon as possible. ${ }^{2}$ Major problems remained in the timeliness and coverage of general government statistics and in the quality of balance of payments estimates, particularly for remittances, due mainly to lack of capacity. The recent data ROSC (see accompanying paper) provides a blueprint for needed technical and institutional improvements.

\section{A. Fiscal Policy}

\section{The authorities acknowledged the risk of a general government deficit emerging} in 2007 but saw little scope for adjusting policies.

- $\quad$ The RS budget was based on conservative assumptions and targeted a broad balance (including municipalities and extrabudgetary funds but excluding foreign-financed projects) and its implementation was on track. The RS government, however, did not rule out a supplementary budget later in the year.

\begin{tabular}{|c|c|c|}
\hline \multicolumn{3}{|c|}{$\begin{array}{l}\text { General Government: Overall Balance } \\
\text { (in percent of GDP) }\end{array}$} \\
\hline & 2006 & 2007 \\
\hline $\begin{array}{l}\text { General government } \\
\text { of which: }\end{array}$ & 3.0 & -1.4 \\
\hline RS & 0.4 & 0.0 \\
\hline $\begin{array}{l}\text { Federation } \\
\text { of which: cantons }\end{array}$ & $\begin{array}{l}2.3 \\
0.6\end{array}$ & $\begin{array}{l}-0.6 \\
-0.7\end{array}$ \\
\hline Foreign financed projects & -0.6 & -0.7 \\
\hline
\end{tabular}

- $\quad$ The public finances in the Federation, both at Entity and cantonal levels, would come under pressure this year as a result of unfunded pre-electoral hikes in demobilized soldiers' benefits. The Entity government did not intend to roll back these hikes, but was confident that its present budget had sufficient margin to cover the additional spending. Instead, it intended to focus on consolidating the legal framework and administration of the multitude of veteran benefits. As regards cantons, since the additional spending would be financed by a drawdown of deposits from accumulated surpluses from 2006, it was not subject to any top-down constraint. The consolidated Federation budget (including all levels of government and extrabudgetary funds but excluding foreign-financed projects) would thus likely record a sizeable deficit.

- $\quad$ The State budget was fully funded and broadly balanced. The State government saw no need for action on its part to offset deficits in other parts of the general government

\footnotetext{
${ }^{2}$ Following the discussions, the State Statistical Agency presented the first expenditure-side estimates of GDP for 2004 and 2005. These figures, not yet incorporated in the staff tables, show an upward revision of GDP by about 15 percent as a result of improved estimates of the gray economy. Combined with last year's upward revision, this comes close to staff's earlier estimates of unrecorded activity.
} 
14. Staff expressed concern about the prospect of a large deterioration in the general government position in 2007. A swing estimated at $4 \frac{1}{2}$ percentage points of GDP in the general government balance would reverse the prudent fiscal management of recent years and have repercussions for aggregate demand. To limit this swing, staff urged the RS to stick to the spending levels in its original budget and save any higher-than-projected revenue, and the Federation government to take measures to offset the likely deficits in cantonal budgets. Staff supported the Federation government's plan to consolidate the various laws dealing with demobilized soldiers' benefits but cautioned that this would be insufficient to generate the required savings.

15. The governments' ambitious infrastructure investment plans, coupled with the availability of substantial privatization receipts, raised questions about the authorities' medium-term fiscal policy intentions. Staff noted that both Entity governments' programs envisaged large road-building projects (in the Federation alone, these amounted to 17 percent of 2006 GDP over the coming four years). At the same time, the proceeds from large privatizations would provide a ready source of cash: the RS government would receive $7 \frac{1}{2}$ percent of GDP this year from the sale of RS Telekom and oil refineries, and the Federation could expect 2-4 percent of GDP over the next two years if it launched privatization in earnest. How would these investment projects be managed and financed? How would the privatization receipts be used? And how did both fit into the governments' medium-term fiscal plans?

\section{The authorities did not have a comprehensive medium-term strategy for the} entire general government sector. All governments underscored their commitment to a responsible fiscal policy, aware that this was the only macroeconomic management tool in a currency board. This meant aiming their individual budgets at a balance or small surplus over the medium term while gradually lowering their expenditure-to-GDP ratios. But these targets did not cover all parts of the government, such as projects financed by foreign sources or privatization receipts. And no authority was in a position to articulate clear medium-term fiscal policy objectives for Bosnia \& Herzegovina as a whole.

- $\quad$ Both Entity governments stressed that they did not intend to use privatization receipts to finance current spending. The RS government had a well-developed-but not yet fully-approved - plan that envisaged setting aside about 15 percent of these receipts to fund pension reform (on which it had started preparatory work with World Bank assistance) and using the rest to (i) finance public investment projects and (ii) support strategic sectors through the banking system. It emphasized that the allocation decisions for the latter would be done by commercial banks on business grounds. The Federation also envisaged using future privatization receipts for investment and support of key sectors but did not have concrete plans at the time of the discussions. 
- As regards the financing of infrastructure investment, notably road construction, the 2007 Entity budgets already included several small projects. For larger projects, Entity governments envisaged using a combination of concessions and public-private partnerships. A number of feasibility studies were completed or underway, but no comprehensive plan existed so far for the country as a whole. Staff expressed reservations about the current institutional capacity to handle public-private partnerships, especially for large projects, but the authorities were confident that they could manage these arrangements.

17. The authorities were aware of the risks arising from some unsettled categories of claims against the government. Significant progress had been made (reported in last year's consultation) in determining fiscally responsible settlement terms for frozen foreign currency deposits (FFCDs), war damage, and other claims. However, proposed amendments to the law on FFCDs and pending lawsuits could undermine these arrangements, while the size and settlement terms for restitution claims were still undecided. The State government agreed that the potential cost of the FFCD amendments could be significant. While not ruling out minor revisions in the settlement terms, it intended to stick as close as possible to the original law. It also planned to finalize a restitution law that would cap financial compensation and set terms consistent with fiscal sustainability.

18. Staff advocated aiming at a general government balance over the medium term. The currency board arrangement, uncertainties regarding the size and settlement terms of some government liabilities, and the declining concessionality of government debt justified a conservative target. A balanced budget would reduce the public debt-to-GDP ratio (including debt assumptions to cover domestic claims) to about 40 percent of GDP by 2012 and provide sufficient cushion for plausible shocks (Appendix I). It would also be a simple anchor for policymakers and the public. Achieving an overall balance while reducing the tax burden and making room for priority investments will require cuts in current spending, where there is ample scope for savings identified in the recent World Bank Public Expenditure Review.

\section{B. Improving Policy Coordination and Creating a Single Economic Space}

\section{The discussion of fiscal policy highlighted the insidious effect of lack of policy} coordination. The fragmentation of fiscal authority and complexity of inter-governmental fiscal relations is a by-product of Bosnia \& Herzegovina's constitutional setup and could thus best be addressed in the context of fundamental constitutional reform. But the problem is aggravated by lack of cooperation between the various governments in setting and pursuing their fiscal policy objectives.

20. The authorities were taking steps to improve fiscal policy coordination. They intended to strengthen the legal basis for the Fiscal Council that would set targets and coordinate fiscal policy for the country as a whole. The Council, including the Prime 
Ministers and Finance Ministers of the Entities and the State, was already operating in a rudimentary fashion. The authorities had prepared a draft law that would provide a firm legal basis, formalize procedures, and define the scope of coordination of budgetary policy. Moreover, they argued that the statutory borrowing limits were an important additional coordinating and disciplining device.

\section{Staff welcomed these steps despite some reservations, but argued that they} would not be sufficient to ensure effective coordination. The draft Fiscal Council law provided appropriate voting and deadlock-breaking rules, but the definition of the consolidated budget balance excluded most capital spending and the penalties envisaged for noncompliance were weak. Staff urged the Federation to approve as soon as possible the law on borrowing limits, and all governments to improve public financial management so that the limits could be effective. It cautioned, however, that fiscal rules and institutions alone were not sufficient to guarantee effective coordination and sound policies: political will to cooperate was paramount. Absent that, the borrowing limits, even if effective, may force piecemeal and suboptimal expenditure adjustments on various levels of government and might not prove politically sustainable.

\section{The creation of a single economic space in Bosnia \& Herzegovina was still} unfinished business. Staff noted that the last few years had seen significant economic convergence between the two Entities, as the economy of the RS caught up with the Federation, but few signs of economic integration between them and even among cantons in the Federation (see accompanying Selected Issues paper, Chapter V). Labor and business mobility was impeded by a myriad of regulatory and tax barriers. The authorities outlined plans to reform corporate and personal income taxes, simplify the process for obtaining business permits, reduce regulations, and simplify inspections. In these areas, the RS had already made significant progress, and action was now needed by the Federation. Staff welcomed this but noted that creating a single economic space would require farther-reaching reforms, notably (i) harmonizing the laws on securities and companies; (ii) amending labor legislation to stop the accumulation of wage claims in cases where workers were not effectively employed by the company, thus allowing workers to switch employers without first having to settle existing claims; (iii) harmonizing the base for employers' contributions on wages; and (iv) ensuring the portability of pension and health benefits across cantonal and Entity borders. The authorities were non-committal. The RS government, in particular, was concerned that emphasizing harmonization with the Federation might imply slowing down the pace of their own reforms.

\section{Ensuring Financial Stability}

23. Authorities and staff agreed that the pace of financial deepening per se was not a concern, but financial stability required close attention. The $\mathrm{CBBH}$ stressed that the recent extension of the credit registry to individuals in 2007 would help improve banks' risk 
management. In addition, given its mandate in the area of financial stability, the $\mathrm{CBBH}$ with assistance from the Eurosystem central banks and the Fund was upgrading its monitoring and analysis of the financial sector and had started preparing regular Financial Stability Reports.

24. Staff welcomed these steps but felt that more could be done to safeguard system soundness and weaken the link between credit expansion and foreign borrowing. In particular, it noted that under competitive pressures, some banks may be assuming higher credit risk; that some large banks were repeatedly fined for violations of prudential rules, which suggested that fines were low; and that current regulations created a bias in favor of bank borrowing from abroad to finance credit. To address these concerns, the two Entity supervisory agencies should:

- Tighten loan classification by moving loans with payments overdue more than 30 days to category $\mathrm{C}$ gradually over the next $12-18$ months.

- $\quad$ Raise the fines for noncompliance with prudential regulations.

- $\quad$ Relax the maturity matching requirement between banks' assets and liabilities in order to reduce the need for foreign borrowing to finance credit. This should be done gradually and with appropriate prudential safeguards to ensure adequate bank liquidity.

25. Staff reiterated the recommendation to unify bank supervision either at the CBBH or in a new, independent agency. A single supervisor was necessary for financial sector stability, as well as for establishing cooperation with key foreign supervisors, some of whom were hesitating to conclude Memoranda of Understanding with the Entity agencies. Staff also recommended strengthening the legal and supervisory framework for insurance and leasing. While accepting the economic rationale of these recommendations, the governments - particularly in the RS - noted that they would imply a transfer of competencies from Entities to a State-level agency. They could therefore not be decided separately from the broader constitutional debate. Against this background, staff advised the authorities at least to improve cooperation between the domestic supervisors and the $\mathrm{CBBH}$.

\section{StAFF APPRAISAL}

26. Bosnia \& Herzegovina is in its fourth year of strong and stable growth. This largely reflects the benign international environment and the effects of past reforms in key sectors and the financial system, as well as the benefits of the currency board.

27. The authorities should take advantage of this opportunity to address longstanding distortions. Many of these distortions, such as the large and inefficient public sector, segmented labor market, and overregulated business environment, are to some extent 
a reflection of the more fundamental constitutional problems and ethnic divisions facing the country. But even within this fragmented governance framework, much can be done to improve macroeconomic management, strengthen financial stability, and facilitate private sector development. Achieving this requires a deeper sense of ownership of and commitment to economic reforms, and stronger political will to cooperate, than currently apparent.

28. Urgent action is needed to limit the deterioration in the fiscal position this year and set the basis for prudent fiscal policies in the medium term. To minimize the incipient fiscal relaxation in 2007, the RS government should stick to the expenditure plans in its original budget and the Federation government should act to offset the deficits likely to arise in cantons. To ensure fiscal sustainability, borrowing limits alone will not be sufficient: a comprehensive medium-term fiscal framework for the general government is needed. This framework should aim at maintaining a general government balance, in light of the exigencies of the currency board and uncertainties regarding the size of government liabilities. Fiscal sustainability also requires rejecting proposed amendments to the FFCD law and ensuring that financial restitution is capped at a fiscally responsible level. Private sector involvement in infrastructure is appropriate but poses risks: public-private partnerships can result in significant future public liabilities and should not be used unless a strong institutional framework is in place.

29. Privatization receipts are both an opportunity and a challenge. In the absence of nonconcessional public debt that could be repaid, genuine one-off expenses that boost growth would not jeopardize debt dynamics if financed by privatization, even if they temporarily raise the recorded deficit. Plans to use part of privatization receipts for pension reform are appropriate. But using them to finance private business development in "strategic sectors" is not a good option: if the business environment is improved, the private sector should be able to accomplish this without government support; if not, government support will make little difference and the money may be wasted. In addition, sizeable privatization revenue may complicate liquidity management in the financial system and jeopardize macroeconomic stability. To avoid this, the Entity governments should deposit these receipts abroad or with the $\mathrm{CBBH}$ until it is time to spend them, and spread out their use over time.

30. Improvements in fiscal policy coordination are urgently needed. The statutory borrowing limits are a good first step. The authorities' intention to establish a firm legal basis for the Fiscal Council is welcome, but the current draft law should expand the definition of the general government to cover all public investment and strengthen penalties for noncompliance. Ultimately, however, these institutional improvements will not be sufficient to ensure effective coordination and good fiscal outcomes without the political will to cooperate.

31. Although the real exchange rate does not appear misaligned, structural reforms are important for safeguarding competitiveness, as well as for creating a single 
economic space. Recent balance of payments trends assuage earlier concerns about the viability of the currency board and, notwithstanding serious data weaknesses that complicate an accurate assessment, the level of the exchange rate appears appropriate. But going forward, reforms to restructure the corporate sector, improve the business environment, make the country more attractive for foreign investment, and deregulate the labor market are key for sustaining competitiveness. Harmonizing corporate income taxes, employers' contributions, and capital market legislation, ensuring the portability of pension and health benefits, and facilitating labor mobility are also critical for internal economic integration.

\section{Maintaining financial stability requires improving credit risk management} further, closing gaps in nonbank oversight, and unifying bank supervision. Staff welcomes the extension of the credit registry to individuals and the initiatives of the $\mathrm{CBBH}$ in monitoring financial stability and coordinating supervision. Tightening loan loss classification, raising penalties for noncompliance, and relaxing maturity matching requirements would boost system soundness and weaken the link between credit expansion and foreign borrowing. While necessary, these steps would not be sufficient to ensure an appropriate framework: strengthening the regulatory framework for insurance and leasing and ultimately unifying bank supervision are also necessary.

33. Statistics are not adequate for effective surveillance. Recent improvements notwithstanding, major problems remain in the timeliness and coverage of general government statistics and in the quality of balance of payments estimates. The authorities should persevere with the improvements currently underway and follow up on the recommendations of the recent data ROSC.

\section{Bosnia \& Herzegovina has not accepted the obligations under Article VIII,}

Sections 2, 3 and 4 but maintains restrictions on the transferability of balances and interest accrued on frozen foreign currency deposits. Staff does not recommend approval of these restrictions.

35. It is proposed that the next consultation with Bosnia \& Herzegovina take place on the standard 12-month cycle. 
Table 1. Bosnia and Herzegovina: Selected Economic Indicators, 2003-07

\begin{tabular}{|c|c|c|c|c|c|}
\hline & 2003 & 2004 & 2005 & $\begin{array}{r}2006 \\
\text { Est. }\end{array}$ & $\begin{array}{r}2007 \\
\text { Proj. }\end{array}$ \\
\hline Nominal GDP (millions of KM) 1/ & 13,492 & 14,678 & 15,791 & 17,750 & 19,740 \\
\hline Gross national saving (in percent of GDP) & -0.5 & -0.3 & 0.3 & 4.7 & 6.4 \\
\hline Gross investment (in percent of GDP) & \multicolumn{4}{|c|}{ (Percent change) } & 19.8 \\
\hline Real GDP & 3.5 & 6.1 & 5.0 & 6.0 & 6.0 \\
\hline $\begin{array}{l}\text { Index of industrial production (period average) } 2 / \\
\text { Gross wages (period average) } 2 /\end{array}$ & $\begin{array}{l}3.0 \\
8.5\end{array}$ & $\begin{array}{r}13.6 \\
3.7\end{array}$ & $\begin{array}{r}11.0 \\
5.5\end{array}$ & $\begin{array}{r}10.4 \\
9.2\end{array}$ & $\begin{array}{l}6.0 \\
7.8\end{array}$ \\
\hline $\mathrm{CPI}$ (period average) $2 /$ & 0.5 & 0.3 & 3.6 & 7.5 & 2.5 \\
\hline \multicolumn{6}{|l|}{ Money and credit (end of period) } \\
\hline Broad money & 10.0 & 24.3 & 18.2 & 24.7 & 21.0 \\
\hline Total credit & 25.4 & 31.1 & 27.7 & 20.6 & 22.0 \\
\hline Of which: credit to the private sector & 24.8 & $\begin{array}{l}27.5 \\
\text { (In pe }\end{array}$ & $\begin{array}{r}27.5 \\
\text { ent of GD }\end{array}$ & 23.3 & 25.5 \\
\hline \multicolumn{6}{|l|}{ General government budget } \\
\hline Revenue & 50.4 & 47.5 & 48.8 & 50.6 & 49.0 \\
\hline Of which: grants & 6.3 & 3.3 & 3.2 & 2.6 & 2.5 \\
\hline Expenditure (on a commitment basis) & 52.2 & 48.1 & 47.8 & 47.6 & 50.4 \\
\hline Of which: investment expenditure & 10.8 & 7.5 & 7.3 & 6.4 & 7.2 \\
\hline Primary balance & -1.0 & 0.1 & 1.6 & 3.6 & -0.7 \\
\hline Overall balance & -1.8 & -0.5 & 1.0 & 3.0 & -1.4 \\
\hline External public debt & 30.2 & 27.5 & 27.5 & 22.9 & 20.5 \\
\hline NPV of external public debt & 23.1 & 21.0 & 21.0 & 17.5 & 15.7 \\
\hline Total public debt $3 /$ & $\begin{array}{c}30.6 \\
\text { (In millio }\end{array}$ & $\begin{array}{r}27.5 \\
\text { s of euro }\end{array}$ & $\begin{array}{r}27.5 \\
\text { unless n }\end{array}$ & $\begin{array}{r}23.4 \\
\text { ted other }\end{array}$ & $\begin{array}{r}39.4 \\
\text { se) }\end{array}$ \\
\hline \multicolumn{6}{|l|}{ Balance of payments } \\
\hline Exports of goods and services & 1,939 & 2,402 & 2,905 & 3,575 & 4,134 \\
\hline Imports of goods and services & 5,313 & 5,704 & 6,465 & 6,495 & 7,431 \\
\hline Unrequited transfers, net & 1,462 & 1,489 & 1,486 & 1,508 & 1,577 \\
\hline Current account balance & $-1,439$ & $-1,482$ & $-1,750$ & $-1,044$ & $-1,357$ \\
\hline (In percent of GDP) & -20.9 & -19.7 & -21.7 & -11.5 & -13.4 \\
\hline Foreign direct investment & 338 & 533 & 420 & 338 & 1,163 \\
\hline (In percent of GDP) & 4.9 & 7.1 & 5.2 & 3.7 & 11.5 \\
\hline Gross official reserves & 1,422 & 1,768 & 2,145 & 2,761 & 3,254 \\
\hline (In months of imports) & 3.2 & 3.7 & 4.0 & 5.1 & 5.3 \\
\hline Net international reserves (in percent of private sector deposits) & 69.7 & 68.3 & 69.0 & 71.4 & 69.2 \\
\hline External debt service & 289 & 364 & 234 & 319 & 322 \\
\hline (In percent of exports of goods and services) & 14.9 & 15.2 & 8.1 & 8.9 & 7.8 \\
\hline
\end{tabular}

Sources: Bosnian authorities; and IMF staff estimates and projections.

1/ National accounts estimates are preliminary. They are being revised with the help of Fund technical assistance.

2/ Based on weighted averages for the Federation and Republika Srpska.

3/ Increase in 2007 reflects recognition of domestic claims. 
Table 2. Bosnia and Herzegovina: Balance of Payments, 2003-12

(In millions of euros, unless otherwise indicated)

\begin{tabular}{|c|c|c|c|c|c|c|c|c|c|c|}
\hline & 2003 & 2004 & 2005 & 2006 & 2007 & 2008 & 2009 & 2010 & 2011 & 2012 \\
\hline & & & & Est. & \multicolumn{6}{|c|}{ Projections } \\
\hline Merchandise trade & $-3,671$ & $-3,678$ & $-4,006$ & $-3,406$ & $-3,858$ & $-3,966$ & $-4,160$ & $-4,401$ & $-4,572$ & $-4,752$ \\
\hline Exports, f.o.b. & 1,303 & 1,677 & 2,087 & 2,687 & 3,149 & 3,721 & 4,040 & 4,164 & 4,347 & 4,533 \\
\hline Imports, f.o.b. & $-4,974$ & $-5,354$ & $-6,093$ & $-6,093$ & $-7,007$ & $-7,687$ & $-8,200$ & $-8,566$ & $-8,919$ & $-9,285$ \\
\hline Reconstruction & -351 & -279 & -240 & -186 & -152 & -208 & -196 & -187 & -159 & -154 \\
\hline Other & $-4,623$ & $-5,076$ & $-5,852$ & $-5,907$ & $-6,855$ & $-7,479$ & $-8,003$ & $-8,378$ & $-8,760$ & $-9,131$ \\
\hline Services, net & 297 & 376 & 446 & 486 & 561 & 607 & 654 & 704 & 754 & 807 \\
\hline Exports & 636 & 725 & 817 & 888 & 985 & 1,062 & 1,133 & 1,203 & 1,274 & 1,350 \\
\hline Imports & -339 & -349 & -372 & -402 & -424 & -455 & -479 & -499 & -520 & -543 \\
\hline Income, net & 473 & 331 & 324 & 368 & 363 & 246 & 241 & 275 & 285 & 256 \\
\hline Credit & 579 & 461 & 502 & 548 & 600 & 600 & 618 & 666 & 712 & 734 \\
\hline Debit & -106 & -131 & -178 & -180 & -237 & -354 & -377 & -392 & -427 & -478 \\
\hline Of which: interest & -88 & -79 & -85 & -82 & -93 & -103 & -110 & -124 & -135 & -146 \\
\hline Current transfers, net & 1,462 & 1,489 & 1,486 & 1,508 & 1,577 & 1,641 & 1,709 & 1,781 & 1,796 & 1,834 \\
\hline Receipts & 1,571 & 1,658 & 1,646 & 1,687 & 1,756 & 1,821 & 1,889 & 1,960 & 1,976 & 2,013 \\
\hline Public & 298 & 276 & 231 & 149 & 167 & 179 & 194 & 211 & 170 & 150 \\
\hline Private & 1,273 & 1,381 & 1,415 & 1,538 & 1,589 & 1,641 & 1,695 & 1,750 & 1,806 & 1,863 \\
\hline Payments & -109 & -169 & -161 & -180 & -180 & -180 & -180 & -180 & -180 & -180 \\
\hline Current account balance & $-1,439$ & $-1,482$ & $-1,750$ & $-1,044$ & $-1,357$ & $-1,472$ & $-1,556$ & $-1,642$ & $-1,737$ & $-1,855$ \\
\hline Capital and Financial Accounts & 1,332 & 1,469 & 1,782 & 1,254 & 1,505 & 2,084 & 1,871 & 1,816 & 1,326 & 1,494 \\
\hline Capital account & 411 & 391 & 367 & 272 & 449 & 494 & 488 & 490 & 473 & 484 \\
\hline Capital transfers & 411 & 391 & 367 & 272 & 449 & 494 & 488 & 490 & 473 & 484 \\
\hline Official transfers & 170 & 135 & 116 & 90 & 84 & 117 & 98 & 88 & 57 & 56 \\
\hline Private transfers & 241 & 256 & 251 & 182 & 366 & 377 & 390 & 402 & 415 & 429 \\
\hline Financial account & 921 & 1,078 & 1,415 & 982 & 1,056 & 1,590 & 1,383 & 1,325 & 853 & 1,010 \\
\hline Direct investment & 338 & 533 & 420 & 338 & 1,163 & 1,150 & 947 & 942 & 470 & 451 \\
\hline Outward & 0 & -1 & -1 & 0 & 0 & 0 & 0 & 0 & 0 & 1 \\
\hline Inward & 338 & 534 & 421 & 338 & 1,163 & 1,150 & 947 & 942 & 470 & 450 \\
\hline Portfolio investment & 0 & 0 & 0 & 0 & -600 & 55 & 46 & 49 & 52 & 55 \\
\hline Other investment & 584 & 545 & 995 & 644 & 493 & 386 & 390 & 335 & 331 & 504 \\
\hline Assets (increase, - ) & 89 & 266 & 292 & 280 & 183 & -8 & -16 & -22 & -53 & 57 \\
\hline Commercial banks & -48 & -176 & -94 & -119 & -125 & -139 & -128 & -115 & -124 & 0 \\
\hline Other & 136 & 442 & 386 & 399 & 308 & 130 & 112 & 93 & 71 & 57 \\
\hline Liabilities & 495 & 279 & 704 & 364 & 311 & 394 & 407 & 357 & 384 & 447 \\
\hline Trade credits & 62 & 77 & 199 & 190 & 186 & 230 & 239 & 245 & 261 & 269 \\
\hline Commercial banks & 395 & 238 & 339 & 269 & 261 & 295 & 278 & 254 & 277 & 350 \\
\hline Amortization & -156 & -247 & -116 & -200 & -216 & -232 & -219 & -252 & -265 & -281 \\
\hline Drawing of loans & 194 & 211 & 282 & 105 & 78 & 101 & 108 & 109 & 112 & 108 \\
\hline Project & 181 & 144 & 124 & 95 & 68 & 91 & 98 & 99 & 102 & 98 \\
\hline Program & 30 & 32 & 10 & 10 & 10 & 10 & 10 & 10 & 10 & 10 \\
\hline Reserve assets (increase, - ) & -162 & -346 & -378 & -616 & -493 & -958 & -660 & -519 & 66 & 16 \\
\hline Monetary gold & 0 & 0 & 0 & 0 & 0 & 0 & 0 & 0 & 0 & 0 \\
\hline Special drawing rights & 0 & 2 & 0 & 0 & 0 & 0 & 0 & 0 & 0 & 0 \\
\hline Reserve position in the IMF & 0 & 0 & 0 & 0 & 0 & 0 & 0 & 0 & 0 & 0 \\
\hline Foreign exchange & -162 & -348 & -378 & -616 & -493 & -958 & -660 & -519 & 66 & 16 \\
\hline Other claims & 0 & 0 & 0 & 0 & 0 & 0 & 0 & 0 & 0 & 0 \\
\hline Net Errors and Omissions 1/ & 268 & 358 & 345 & 406 & 345 & 345 & 345 & 345 & 345 & 345 \\
\hline \multicolumn{11}{|l|}{ Memorandum items: } \\
\hline Current account balance (percent of GDP) & -20.9 & -19.7 & -21.7 & -11.5 & -13.4 & -13.5 & -13.5 & -13.5 & -13.5 & -13.5 \\
\hline Trade balance (percent of GDP) & -53.2 & -49.0 & -49.6 & -37.5 & -38.2 & -36.3 & -36.0 & -36.1 & -35.4 & -34.6 \\
\hline Import of goods (change, percent) & 6.0 & 7.6 & 13.8 & 0.0 & 15.0 & 9.7 & 6.7 & 4.5 & 4.1 & 4.1 \\
\hline Export of goods (change, percent) & 11.5 & 28.7 & 24.5 & 28.7 & 17.2 & 18.2 & 8.6 & 3.1 & 4.4 & 4.3 \\
\hline Transfers (percent of GDP) & 21.2 & 19.8 & 18.4 & 16.6 & 15.6 & 15.0 & 14.8 & 14.6 & 13.9 & 13.4 \\
\hline Net foreign direct investment (percent of GDP) & 4.9 & 7.1 & 5.2 & 3.7 & 11.5 & 10.5 & 8.2 & 7.7 & 3.6 & 3.3 \\
\hline External debt/GDP (percent) & 53.3 & 51.1 & 56.4 & 50.7 & 48.5 & 47.9 & 48.2 & 48.3 & 48.2 & 48.4 \\
\hline Private & 23.0 & 23.6 & 28.9 & 27.9 & 28.1 & 28.9 & 30.1 & 30.9 & 31.6 & 32.6 \\
\hline Public & 30.2 & 27.5 & 27.5 & 22.9 & 20.5 & 19.0 & 18.2 & 17.4 & 16.6 & 15.8 \\
\hline External public debt service/exports of G\&S (percent) & 14.9 & 15.2 & 8.1 & 8.9 & 7.8 & 7.0 & 6.4 & 7.0 & 7.1 & 7.3 \\
\hline Gross official reserves & 1,422 & 1,768 & 2,145 & 2,761 & 3,254 & 4,212 & 4,871 & 5,390 & 5,324 & 5,309 \\
\hline (Months of imports of goods and services) & 3.2 & 3.7 & 4.0 & 5.1 & 5.3 & 6.2 & 6.7 & 7.1 & 6.8 & 6.5 \\
\hline Nominal GDP & 6,898 & 7,505 & 8,074 & 9,076 & 10,093 & 10,936 & 11,556 & 12,181 & 12,907 & 13,726 \\
\hline
\end{tabular}

Sources: Bosnian authorities; and IMF staff estimates and projections.

1/ Errors and omissions are explicitly projected to capture unrecorded capital inflows. 
Table 3. Bosnia and Herzegovina: Vulnerability Indicators, 2004-07

\begin{tabular}{|c|c|c|c|c|}
\hline & 2004 & 2005 & $\begin{array}{r}2006 \\
\text { Est. } \\
\end{array}$ & $\begin{array}{l}2007 \\
\text { Proj. }\end{array}$ \\
\hline Exports of goods (change, percent, in euros) & 28.7 & 24.5 & 28.7 & 17.2 \\
\hline Imports of goods (change, percent, in euros) & 7.6 & 13.8 & 0.0 & 15.0 \\
\hline Current account balance (percent of GDP) & -19.7 & -21.7 & -11.5 & -13.4 \\
\hline Capital and financial account (percent of GDP) & 19.6 & 22.1 & 13.8 & 14.9 \\
\hline Gross official reserves (end of period, millions of euros) & 1,768 & 2,145 & 2,761 & 3,254 \\
\hline In months of imports of goods and services & 3.7 & 4.0 & 5.1 & 5.3 \\
\hline Broad money/NFA (end of period) & 2.5 & 2.9 & 2.7 & 2.7 \\
\hline Foreign exchange deposits/reserves (percent, end of period) & 74.4 & 74.6 & 71.9 & $\cdots$ \\
\hline Total external public debt (percent of GDP) & 27.5 & 27.5 & 22.9 & 20.5 \\
\hline External public debt service/exports of G\&S (percent) 1/ & 15.2 & 8.1 & 8.9 & 7.8 \\
\hline External debt service to the IMF (percent of total debt service) & 35.2 & 29.7 & 28.0 & 10.5 \\
\hline Exchange rate (per U.S. dollar, period average) & 1.57 & 1.57 & 1.56 & $\cdots$ \\
\hline REER (annual average percentage change; depreciation $=-$ ) & -1.6 & 0.7 & 0.4 & $\ldots$ \\
\hline
\end{tabular}

Sources: Bosnian authorities; and IMF staff estimates and projections.

$1 /$ Includes repayment of IMF loans. 
Table 4. Bosnia and Herzegovina: General Government, 2003-07 (In percent of GDP)

\begin{tabular}{|c|c|c|c|c|c|c|}
\hline & \multirow[t]{2}{*}{2003} & \multirow[t]{2}{*}{2004} & \multirow[t]{2}{*}{2005} & \multirow{2}{*}{$\begin{array}{r}2006 \\
\text { Est. }\end{array}$} & \multicolumn{2}{|c|}{2007} \\
\hline & & & & & Budget & Proj. \\
\hline Revenue & 50.4 & 47.5 & 48.8 & 50.6 & 48.1 & 49.0 \\
\hline Tax & 37.0 & 36.8 & 38.3 & 41.2 & 38.7 & 39.7 \\
\hline VAT / sales tax & 10.4 & 11.0 & 11.6 & 15.2 & 13.2 & 13.4 \\
\hline Excises & 5.7 & 5.6 & 6.2 & 5.8 & 5.8 & 5.8 \\
\hline Trade taxes & 4.8 & 3.7 & 3.9 & 3.1 & 3.2 & 3.2 \\
\hline Direct taxes & 2.8 & 2.8 & 2.9 & 3.0 & 2.8 & 2.9 \\
\hline Social security contributions & 13.5 & 13.6 & 13.7 & 14.0 & 13.6 & 14.3 \\
\hline Nontax & 7.0 & 7.4 & 7.3 & 6.7 & 6.9 & 6.9 \\
\hline Grants & 6.3 & 3.3 & 3.2 & 2.6 & 2.5 & 2.5 \\
\hline For budget support & 0.4 & 0.2 & 0.3 & 0.1 & 0.1 & 0.1 \\
\hline For investment & 6.0 & 3.1 & 2.9 & 2.5 & 2.4 & 2.4 \\
\hline Consolidated expenditure on a commitment basis & 52.2 & 48.1 & 47.8 & 47.6 & 49.5 & 50.4 \\
\hline Wage bill & 13.7 & 12.9 & 12.2 & 12.0 & 12.1 & 12.2 \\
\hline Of which: severance package & 0.0 & 0.1 & 0.0 & 0.0 & 0.0 & 0.0 \\
\hline Goods and services & 11.0 & 10.9 & 10.4 & 10.2 & 9.7 & 9.7 \\
\hline Subsidies and transfers to nonpublic agents & 14.1 & 13.8 & 14.1 & 14.8 & 16.1 & 16.5 \\
\hline Social benefits & 7.8 & 8.0 & 8.3 & 8.9 & 9.3 & 9.8 \\
\hline Other transfers to households & 4.9 & 4.4 & 4.4 & 4.3 & 5.0 & 5.0 \\
\hline Subsidies to industry and agriculture & 1.4 & 1.4 & 1.4 & 1.7 & 1.8 & 1.8 \\
\hline Interest payments & 0.8 & 0.6 & 0.6 & 0.6 & 0.6 & 0.6 \\
\hline Other current spending & 1.8 & 2.4 & 3.2 & 3.5 & 4.0 & 4.1 \\
\hline Investment expenditure & 10.8 & 7.5 & 7.3 & 6.4 & 7.0 & 7.2 \\
\hline Foreign-financed investment projects & 8.6 & 5.0 & 4.4 & 3.1 & 3.1 & 3.1 \\
\hline Other investment expenditure & 2.2 & 2.4 & 2.9 & 3.3 & 4.0 & 4.1 \\
\hline Balance & -1.8 & -0.5 & 1.0 & 3.0 & -1.4 & -1.4 \\
\hline Financing & 1.8 & 0.5 & -1.0 & -3.0 & 1.4 & 1.4 \\
\hline Domestic financing & 0.0 & -0.9 & -1.7 & -2.7 & 1.5 & 7.6 \\
\hline GSM proceeds & 0.0 & 0.0 & 0.4 & 0.2 & 0.2 & 0.2 \\
\hline Privatization proceeds & 0.0 & 0.0 & 0.3 & 0.1 & 0.1 & 9.3 \\
\hline FBIH & 0.0 & 0.0 & 0.3 & 0.1 & 0.1 & 1.7 \\
\hline RS & 0.0 & 0.0 & 0.0 & 0.0 & 0.0 & 7.7 \\
\hline Repayment of domestic claims & 0.0 & -0.4 & -0.4 & -0.8 & -0.3 & -0.3 \\
\hline Repayment of other arrears and float & 0.1 & -0.4 & -0.5 & 0.0 & 0.0 & 0.0 \\
\hline Other domestic financing & -0.2 & -0.2 & -1.5 & -2.3 & 1.6 & -1.7 \\
\hline Foreign financing & 1.8 & 1.4 & 0.7 & -0.3 & -0.1 & -6.2 \\
\hline For budget support & 0.4 & 0.4 & 0.1 & 0.1 & 0.0 & 0.0 \\
\hline For investment & 2.6 & 1.9 & 1.5 & 0.6 & 0.7 & 0.7 \\
\hline Amortization & -1.2 & -1.0 & -0.9 & -1.0 & -0.8 & -0.8 \\
\hline Other foreign financing & 0.0 & 0.0 & 0.0 & 0.0 & 0.0 & -6.1 \\
\hline \multicolumn{7}{|l|}{ Memorandum items: } \\
\hline Underlying balance 1/ & -1.8 & -0.5 & 1.0 & 1.5 & $\ldots$ & -1.5 \\
\hline Primary balance & -1.0 & 0.1 & 1.6 & 3.6 & -0.8 & -0.7 \\
\hline
\end{tabular}

Sources: Ministries of Finance; and IMF staff estimates and projections.

$1 /$ Corrected for temporary effects of VAT refunds. 
Table 5. Bosnia and Herzegovina: Elements of General Government, 2003-07

(In percent of GDP)

\begin{tabular}{|c|c|c|c|c|c|c|}
\hline & \multirow[t]{2}{*}{2003} & \multirow[t]{2}{*}{2004} & \multirow[t]{2}{*}{2005} & \multirow{2}{*}{$\begin{array}{r}2006 \\
\text { Est. }\end{array}$} & \multicolumn{2}{|c|}{2007} \\
\hline & & & & & Budget & Proj. \\
\hline \multicolumn{7}{|l|}{ Federation budget } \\
\hline Revenue and grants & 7.4 & 7.1 & 7.0 & 6.4 & 6.2 & 6.4 \\
\hline Expenditure & 7.4 & 6.7 & 5.7 & 4.9 & 6.2 & 6.2 \\
\hline Of which: transfers to other levels of government & 0.4 & 0.5 & 0.0 & 0.0 & 0.0 & 0.0 \\
\hline Balance & 0.0 & 0.4 & 1.2 & 1.5 & 0.0 & 0.2 \\
\hline \multicolumn{7}{|l|}{ Federation Road Fund } \\
\hline Revenue and grants & 0.6 & 0.6 & 0.6 & 0.6 & 0.6 & 0.6 \\
\hline Of which: transfers from the Federation budget & 0.0 & 0.0 & 0.0 & 0.0 & 0.0 & 0.0 \\
\hline Expenditure & 0.6 & 0.6 & 0.8 & 0.7 & 0.7 & 0.7 \\
\hline Balance & 0.0 & 0.0 & -0.1 & -0.1 & -0.1 & -0.1 \\
\hline \multicolumn{7}{|l|}{ Cantonal and municipal budgets } \\
\hline Revenue and grants & 11.7 & 11.8 & 11.6 & 11.9 & 11.7 & 11.4 \\
\hline Of which: transfers from the Federation budget & 0.0 & 0.0 & 0.0 & 0.0 & 0.0 & 0.0 \\
\hline Expenditure & 11.7 & 11.6 & 11.8 & 11.3 & 12.1 & 12.1 \\
\hline Balance & 0.0 & 0.2 & -0.1 & 0.6 & -0.3 & -0.7 \\
\hline \multicolumn{7}{|l|}{ Federation extrabudgetary funds } \\
\hline Revenue and grants & 10.2 & 10.2 & 10.2 & 10.3 & 10.6 & 10.7 \\
\hline Of which: transfers from the Federation budget & 0.0 & 0.0 & 0.0 & 0.0 & 0.0 & 0.0 \\
\hline Expenditure & 10.0 & 9.8 & 10.0 & 10.1 & 10.7 & 10.7 \\
\hline Balance & 0.3 & 0.5 & 0.2 & 0.2 & -0.1 & 0.0 \\
\hline \multicolumn{7}{|l|}{ RS budget and municipalities } \\
\hline Revenue and grants & 9.4 & 8.9 & 9.1 & 9.4 & 8.6 & 9.0 \\
\hline Expenditure & 8.9 & 9.0 & 8.4 & 8.9 & 8.4 & 8.8 \\
\hline Of which: transfers to other levels of government & 0.9 & 1.1 & 1.0 & 1.4 & 0.9 & 0.9 \\
\hline Balance & 0.5 & -0.1 & 0.7 & 0.5 & 0.2 & 0.1 \\
\hline \multicolumn{7}{|l|}{ RS Road Fund } \\
\hline Revenue and grants & 0.0 & 0.4 & 0.4 & 0.4 & 0.4 & 0.4 \\
\hline Of which: transfers from the RS budget & 0.0 & 0.0 & 0.0 & 0.0 & 0.0 & 0.0 \\
\hline Expenditure & 0.0 & 0.4 & 0.5 & 0.6 & 0.5 & 0.5 \\
\hline Balance & 0.0 & 0.0 & -0.1 & -0.2 & -0.2 & -0.1 \\
\hline \multicolumn{7}{|l|}{ RS extrabudgetary funds } \\
\hline Revenue and grants & 4.2 & 4.5 & 4.7 & 5.3 & 4.7 & 5.2 \\
\hline Of which: transfers from the RS budget & 0.7 & 0.8 & 1.0 & 1.3 & 0.9 & 0.9 \\
\hline Expenditure & 4.0 & 4.4 & 4.5 & 5.3 & 4.7 & 5.2 \\
\hline Balance & 0.2 & 0.1 & 0.2 & 0.0 & 0.0 & 0.0 \\
\hline \multicolumn{7}{|l|}{ State } \\
\hline Revenue and grants & 1.3 & 1.6 & 2.4 & 3.9 & 3.7 & 3.7 \\
\hline Of which: transfers from other levels of government & 0.6 & 0.8 & 0.0 & 0.0 & 0.0 & 0.0 \\
\hline Expenditure & 1.4 & 1.6 & 2.1 & 3.6 & 3.8 & 3.8 \\
\hline Balance & -0.1 & 0.1 & 0.3 & 0.3 & -0.1 & -0.1 \\
\hline \multicolumn{7}{|l|}{ ITA } \\
\hline Balance & $\ldots$ & $\ldots$ & 0.4 & 0.6 & $\ldots$ & $\ldots$ \\
\hline \multicolumn{7}{|l|}{ Brcko District } \\
\hline Revenue and grants & 1.4 & 1.4 & 1.1 & 1.1 & 1.0 & 1.1 \\
\hline Expenditure & 1.5 & 1.1 & 1.1 & 1.1 & 1.1 & 1.1 \\
\hline Of which: transfers to other levels of government & 0.0 & 0.0 & 0.0 & 0.0 & 0.0 & 0.0 \\
\hline Balance & -0.1 & 0.3 & 0.0 & 0.1 & -0.1 & -0.1 \\
\hline \multicolumn{7}{|l|}{ Foreign-financed investment projects } \\
\hline Grants & 6.0 & 3.1 & 2.9 & 2.7 & 2.4 & 2.4 \\
\hline Expenditure & 8.6 & 5.0 & 4.4 & 3.2 & 3.1 & 3.1 \\
\hline Balance & -2.6 & -1.9 & -1.5 & -0.6 & -0.7 & -0.7 \\
\hline
\end{tabular}

Sources: Ministries of Finance; and IMF staff estimates and projections. 
Table 6. Bosnia and Herzegovina: Monetary Survey, 2003-07 1/ (In millions of KM)

\begin{tabular}{|c|c|c|c|c|c|}
\hline & 2003 & 2004 & 2005 & $\begin{array}{c}2006 \\
\text { Est. }\end{array}$ & $\begin{array}{r}2007 \\
\text { Proj. }\end{array}$ \\
\hline Net foreign assets & 1,932 & 2,739 & 2,755 & 3,745 & 4,436 \\
\hline Foreign assets & 4,370 & 5,391 & 6,314 & 7,757 & 8,960 \\
\hline Foreign liabilities & 2,438 & 2,652 & 3,559 & 4,012 & 4,524 \\
\hline Domestic credit & 4,630 & 5,465 & 6,977 & 8,411 & 10,260 \\
\hline Claims on central government (net) & -468 & -443 & -553 & -894 & $-1,386$ \\
\hline Claims on noncentral government & 22 & 25 & 32 & 60 & 50 \\
\hline Claims on private sector & 5,076 & 5,883 & 7,498 & 9,245 & 11,596 \\
\hline Non-financial enterprises and cooperatives & 3,017 & 3,146 & 3,924 & 4,735 & 5,811 \\
\hline Households & 1,966 & 2,629 & 3,457 & 4,373 & 5,642 \\
\hline Other & 92 & 108 & 117 & 136 & 143 \\
\hline Broad money & 5,496 & 6,832 & 8,077 & 10,074 & 12,185 \\
\hline Narrow money & 3,113 & 3,535 & 4,108 & 5,071 & 6,093 \\
\hline Currency outside banks & 1,601 & 1,671 & 1,729 & 1,978 & 2,374 \\
\hline Demand deposits of noncentral government & 220 & 343 & 410 & 630 & 700 \\
\hline Demand deposits of the private sector & 1,293 & 1,521 & 1,970 & 2,463 & 3,019 \\
\hline Quasi-money & 2,383 & 3,296 & 3,969 & 5,002 & 6,093 \\
\hline Time and savings deposits in domestic currency & 462 & 703 & 818 & 1,099 & 1,339 \\
\hline Foreign currency deposits & 1,921 & 2,593 & 3,150 & 3,903 & 4,754 \\
\hline Other items (net) & $-1,066$ & $-1,372$ & $-1,655$ & $-2,082$ & $-2,511$ \\
\hline \multicolumn{6}{|l|}{ Memorandum items: } \\
\hline Broad money growth (year-on-year) 2/ & 10.0 & 24.3 & 18.2 & 24.7 & 21.0 \\
\hline NDA growth (year-on-year) & 22.3 & 18.0 & 27.7 & 20.6 & 22.0 \\
\hline NFA growth (year-on-year) & -9.9 & 41.8 & 0.6 & 35.9 & 18.5 \\
\hline Domestic credit contribution to broad money growth (year-on-year) & 16.9 & 15.2 & 22.1 & 17.8 & 26.3 \\
\hline NFA contribution to broad money growth (year-on-year) & -4.2 & 14.7 & 0.2 & 12.2 & 6.9 \\
\hline Broad money (in percent of GDP) & 40.7 & 46.5 & 51.1 & 56.8 & 61.7 \\
\hline Domestic credit (in percent of GDP) & 34.3 & 37.2 & 44.2 & 47.4 & 52.0 \\
\hline Private sector credit (in percent of GDP) & 37.6 & 40.1 & 47.5 & 52.1 & 58.7 \\
\hline Credit to household sector (in percent of GDP) & 14.6 & 17.9 & 21.9 & 24.6 & 28.6 \\
\hline Nominal GDP & 13,492 & 14,678 & 15,791 & 17,750 & 19,740 \\
\hline Velocity of Broad Money & 2.5 & 2.1 & 2.0 & 1.8 & 1.6 \\
\hline Broad money multiplier & 2.1 & 2.1 & 2.0 & 2.0 & 2.0 \\
\hline
\end{tabular}

Sources: Central Bank of Bosnia and Herzegovina; and IMF staff estimates.

1/ Data for March 2005 onward are based on the upgraded classification of general government, so there is a structural break in March 2005. 2/ The jump in broad money growth in 2004 reflects banks' efforts to mobilize foreign currency deposits, following a tightening of end-month forex exposure limits. Further regulatory changes in late 2004 dampened these efforts. 
Table 7. Bosnia and Herzegovina: Monetary Authorities' Balance Sheet 2003-07 (In millions of $\mathrm{KM}$ )

\begin{tabular}{|c|c|c|c|c|c|}
\hline & 2003 & 2004 & 2005 & $\begin{array}{r}2006 \\
\text { Est. }\end{array}$ & $\begin{array}{r}2007 \\
\text { Proj. }\end{array}$ \\
\hline Reserve money & 2,608 & 3,239 & 3,970 & 5,052 & 5,951 \\
\hline Currency outside monetary authorities & 1,722 & 1,817 & 1,907 & 2,154 & 2,589 \\
\hline Currency outside banks & 1,601 & 1,671 & 1,729 & 1,978 & 2,374 \\
\hline Commercial bank cash in vaults & 121 & 147 & 178 & 176 & 215 \\
\hline Commercial bank deposits with $\mathrm{CBBH}$ & 884 & 1,420 & 2,060 & 2,887 & 3,352 \\
\hline Other demand deposits with $\mathrm{CBBH}$ & 2 & 2 & 3 & 10 & 10 \\
\hline Net foreign assets & 2,807 & 3,484 & 4,223 & 5,427 & 6,387 \\
\hline Domestic credit (net) & -18 & -45 & -36 & -124 & -148 \\
\hline Claims on general government (net) & -19 & -45 & -38 & -126 & -150 \\
\hline Claims on the private sector & 0 & 0 & 2 & 2 & 2 \\
\hline Other items (net) & -181 & -201 & -217 & -252 & -288 \\
\hline \multicolumn{6}{|l|}{ 12-month growth rates (percent) } \\
\hline Reserve money & 12 & 24 & 23 & 27 & 18 \\
\hline Net foreign assets & 13 & 24 & 21 & 29 & 18 \\
\hline Net claims on general government & 17 & -11 & 27 & 234 & 19 \\
\hline \multicolumn{6}{|l|}{ Memorandum items: } \\
\hline NFA in percent of currency outside the banks & 175 & 209 & 244 & 274 & 269 \\
\hline NFA in percent of broad money & 51 & 51 & 52 & 54 & 52 \\
\hline
\end{tabular}

Sources: Provided by the monetary authorities; and IMF staff estimates. 
Table 8. Bosnia and Herzegovina: Survey of Domestic Money Banks, 2003-07 1/ ( In millions of KM)

\begin{tabular}{|c|c|c|c|c|c|}
\hline & 2003 & 2004 & 2005 & 2006 & 2007 \\
\hline & & & & Est. & Proj. \\
\hline Net Foreign Assets & -875 & -745 & $-1,467$ & $-1,683$ & $-1,949$ \\
\hline Assets & 1,562 & 1,906 & 2,090 & 2,329 & 2,574 \\
\hline Liabilities & 2,437 & 2,651 & 3,558 & 4,011 & 4,523 \\
\hline Net Domestic Assets & 4,768 & 5,904 & 7,812 & 9,768 & 11,935 \\
\hline Net claims on central government & -449 & -398 & -515 & -768 & $-1,236$ \\
\hline Of which: credits & 24 & 21 & 19 & 8 & 8 \\
\hline Of which: deposits & 473 & 419 & 533 & 760 & 1,228 \\
\hline Claims on non-central government & 22 & 25 & 32 & 60 & 50 \\
\hline Claims on private sector & 5,076 & 5,882 & 7,496 & 9,243 & 11,594 \\
\hline Of which: households & 1,966 & 2,628 & 3,456 & 4,373 & 5,642 \\
\hline Of which: non-financial enterprises and cooperatives & 3,017 & 3,146 & 3,924 & 4,735 & 5,811 \\
\hline Of which: other & 92 & 108 & 117 & 134 & 141 \\
\hline Reserves & 884 & 1,420 & 2,060 & 2,887 & 3,352 \\
\hline Of which: required reserves & 271 & 758 & 1,435 & 1,818 & 2,176 \\
\hline Of which: excess reserves & 613 & 661 & 625 & 1,069 & 1,176 \\
\hline Cash in vaults, not included in reserves & 121 & 147 & 178 & 176 & 215 \\
\hline Other Items (net) & -885 & $-1,170$ & $-1,439$ & $-1,831$ & $-2,040$ \\
\hline Deposits (excl. central government) & 3,893 & 5,159 & 6,345 & 8,085 & 9,986 \\
\hline Deposits in foreign currency & 1,921 & 2,593 & 3,150 & 3,903 & 4,425 \\
\hline Deposits in domestic currency & 1,972 & 2,566 & 3,195 & 4,182 & 5,560 \\
\hline \multicolumn{6}{|l|}{ Memorandum items: } \\
\hline Nominal GDP & 13,492 & 14,678 & 15,791 & 17,750 & 19,740 \\
\hline Adjusted credit to the private sector $2 /$ & 4,613 & 5,882 & 7,496 & 9,243 & 11,594 \\
\hline 12-month growth (percent) & 24.8 & 27.5 & 27.5 & 23.3 & 25.4 \\
\hline Adjusted credit to enterprises & 2,554 & 3,146 & 3,924 & 4,735 & 5,811 \\
\hline 12-month growth (percent) & 17.2 & 23.2 & 24.7 & 20.7 & 22.7 \\
\hline Credit to households (12-month growth, percent) & 36.6 & 33.6 & 31.5 & 26.5 & 29.0 \\
\hline Year-to-date growth of deposits (percent) & 19.5 & 32.5 & 23.0 & 27.4 & 23.5 \\
\hline Year-to-date increase in credit to private sector & 918 & 806 & 1,615 & 1,747 & 2,351 \\
\hline Adjusted credit to the private sector (percent of GDP) 2/ & 34.2 & 40.1 & 47.5 & 52.1 & 58.7 \\
\hline Base for reserves & 5,413 & 7,584 & 9,902 & 12,096 & 14,508 \\
\hline Excess reserves/deposits (in percent) & 15.8 & 12.8 & 9.8 & 13.2 & 11.8 \\
\hline Velocity of deposits & 3.5 & 2.8 & 2.5 & 2.2 & 2.0 \\
\hline
\end{tabular}

Sources: BiH monetary authorities; and IMF staff estimates.

1/ Data for March 2005 onward are based on an upgraded classification of general government, so there is a structural break in March 2005 2/ 2003 data are adjusted to correct for the structural break due to the RS gov't takeover of KM 463 of old bank claims on RS enterprises in June 2004. 
Table 9. Bosnia and Herzegovina: Staff Illustrative Medium-Term Framework, 2004-12 (Baseline)

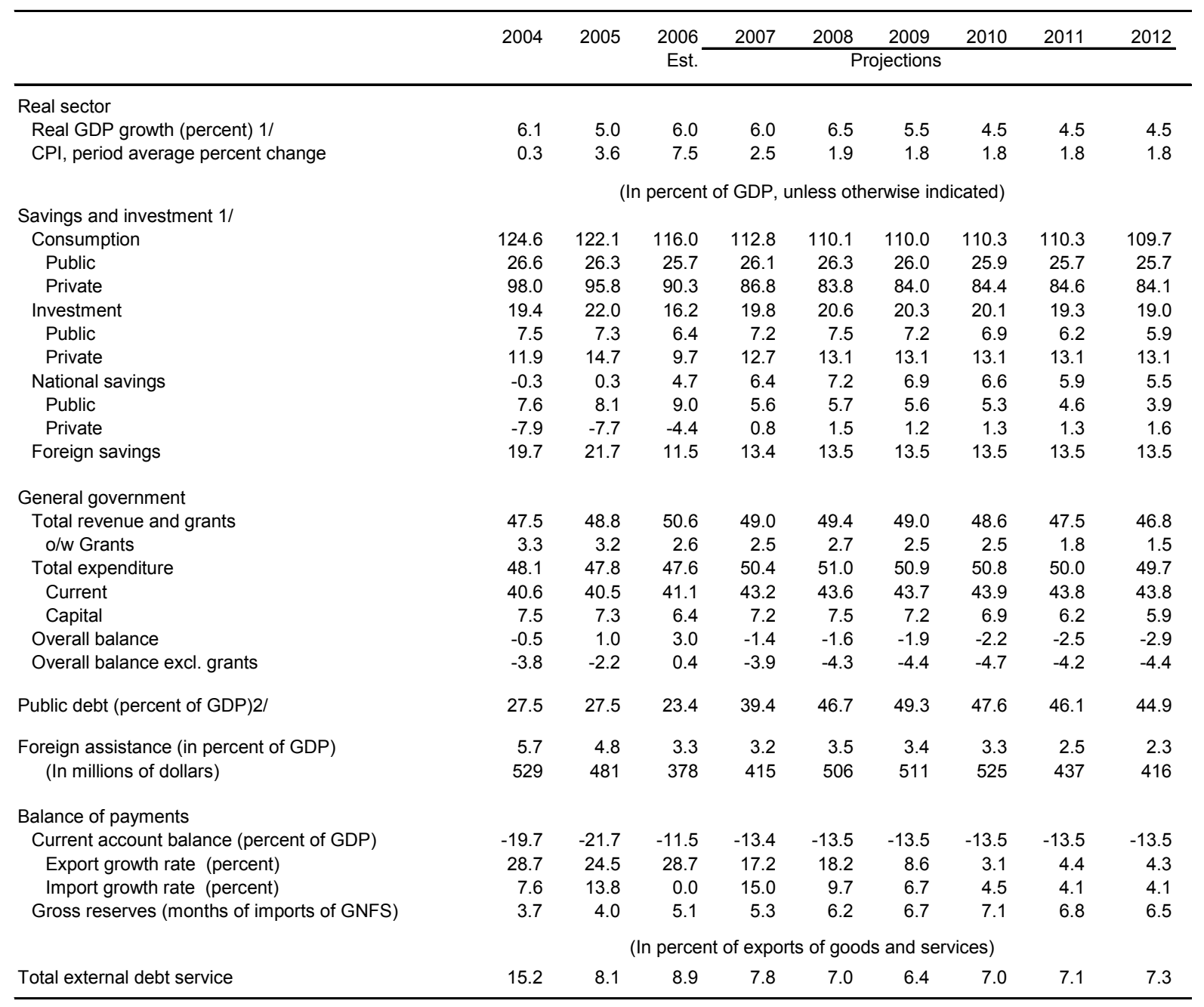

Sources: Bosnian authorities; and IMF staff estimates and projections.

1/ National accounts estimates are preliminary. They are being revised with the help of Fund technical assistance.

2/ Data from 2006 onwards include an estimate of debt assumptions to settle domestic claims on government. 


\section{ATTACHMENT I}

\section{Bosnia AND Herzegovina-DebT SuSTAINABILITy ANALYSIS}

\section{The debt sustainability analysis is based on the staff baseline (unchanged policies)} scenario (Table 9 of the staff report). The medium-term outlook is stable, with growth momentum, even in the absence of reforms; low inflation; further gains in export market share which, in the outer years, are partly offset by declining metals prices (WEO); a broadly unchanged current account deficit; and a gradual deterioration in the fiscal position, which nonetheless keeps the overall balance within a sustainable range for the projection period.

\section{After an initial jump due to settlement of domestic claims, the public debt-to-GDP ratio declines over the projection period, although bound tests show risks. Issuance of bonds to cover domestic claims in 2007-08 is conservatively assumed to total slightly over 30 percentage points of GDP — see details in Box 1. Aside from this, gross financing needs are on the rise, although they appear manageable. A growth slowdown or a further fiscal deterioration, however, could put the debt on an unsustainable path: a one-half standard deviation negative shock to growth or the primary balance would lead to potentially explosive debt dynamics. With the balanced-budget policy recommended by staff, however (Scenario A3), the debt-to-GDP ratio would decline rapidly and the downward trend is not affected by shocks.}

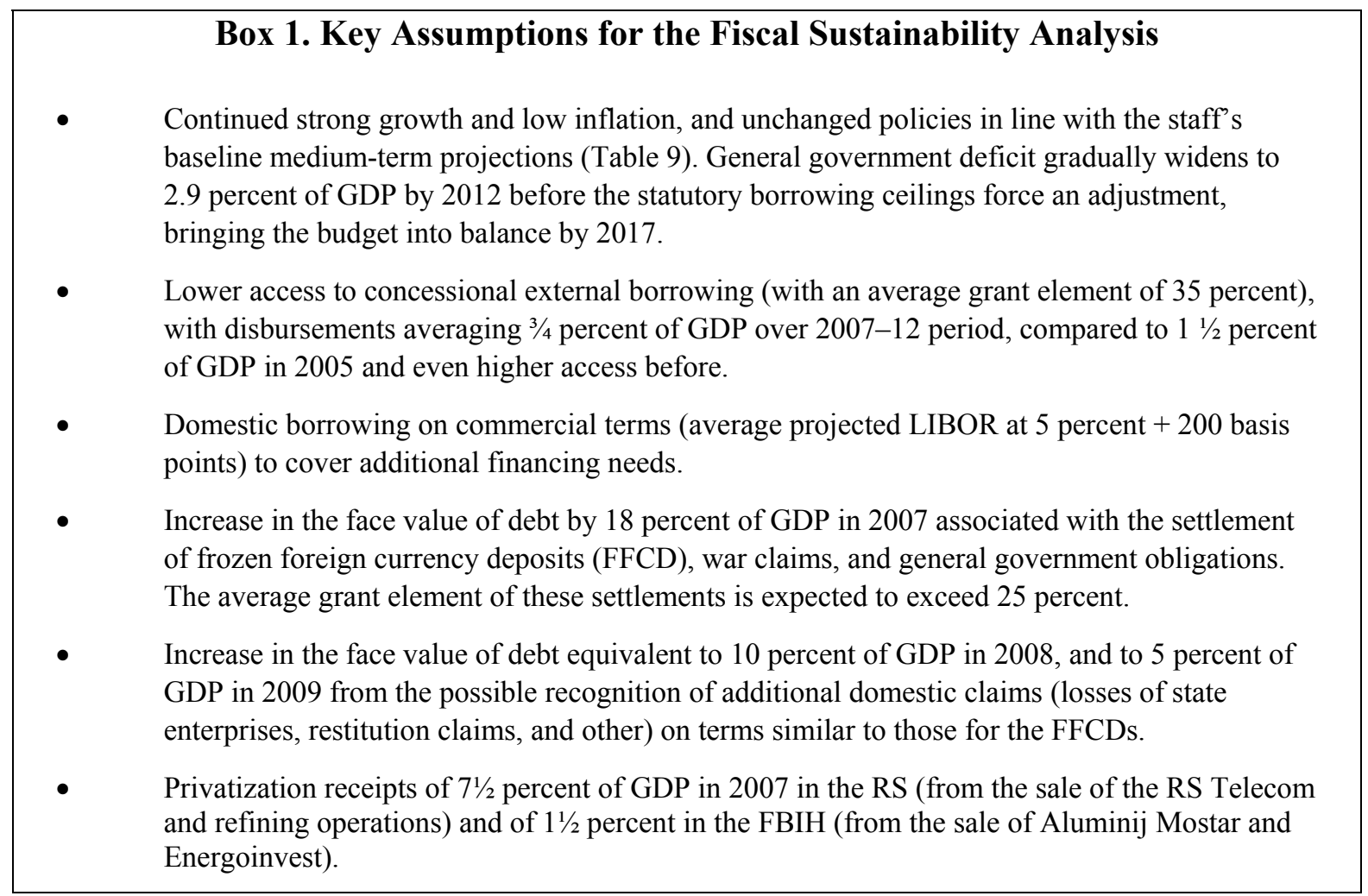




\section{Bosnia \& Herzegovina's external debt is relatively high at 50 percent of GDP, but external sustainability indicators (external debt-to-export and GDP ratio) improve over} the medium term, even in the absence of policy change. This reflects the assumption that economic growth will remain well above the real effective interest rate on external debt, as the latter reflects a large share of concessional debt—notably to the World Bank (Box 2). Gross external financing needs as a percentage of GDP remain constant after peaking in 2007 due to a jump in the demand for imports. Bound tests show limited risks except for shocks to the current account. A change in the borrowing structure (from public to private or from concessional to nonconcessional) could also weaken the dynamics of Bosnia and Herzegovina's external debt, although this risk appears manageable. Finally, an additional risk is that of a liquidity, rather than solvency, crisis. Although the dynamics in the baseline appear reassuring, current account financing will continue to depend heavily on largely unidentified and potentially volatile inflows. Reversal of these inflows could constrain liquidity and either compress imports or force short-term borrowing at much less favorable terms.

\footnotetext{
Box 2. Key Assumptions for the External Debt Sustainability Analysis

- $\quad$ Continued strong growth and low inflation, and unchanged policies in line with the staff's baseline medium-term projections (Table 9).

- $\quad$ Decelerating growth rate of exports and imports (in value), with the export growth rate higher than that of imports.

- $\quad$ Limited access to concessional external borrowing, with new borrowing at market rate. World Bank disbursements declining sharply during the projection period.

- $\quad$ Sustained but gradually declining, inflows of remittances, cross-border and seasonal workers' income.
} 


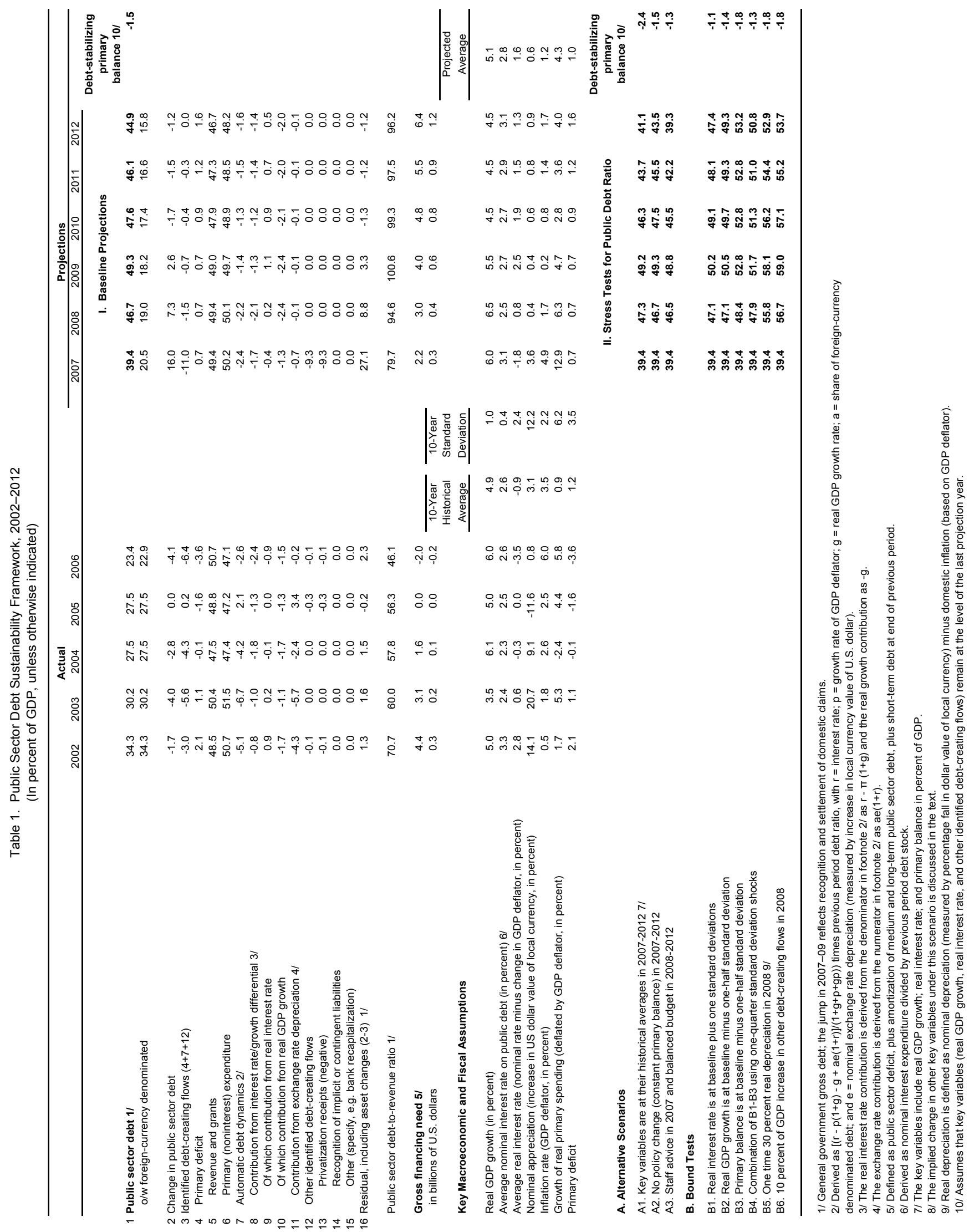


Figure 1. Public Debt Sustainability: Bound Tests 1/

(Public debt in percent of GDP)

Baseline and historical scenarios
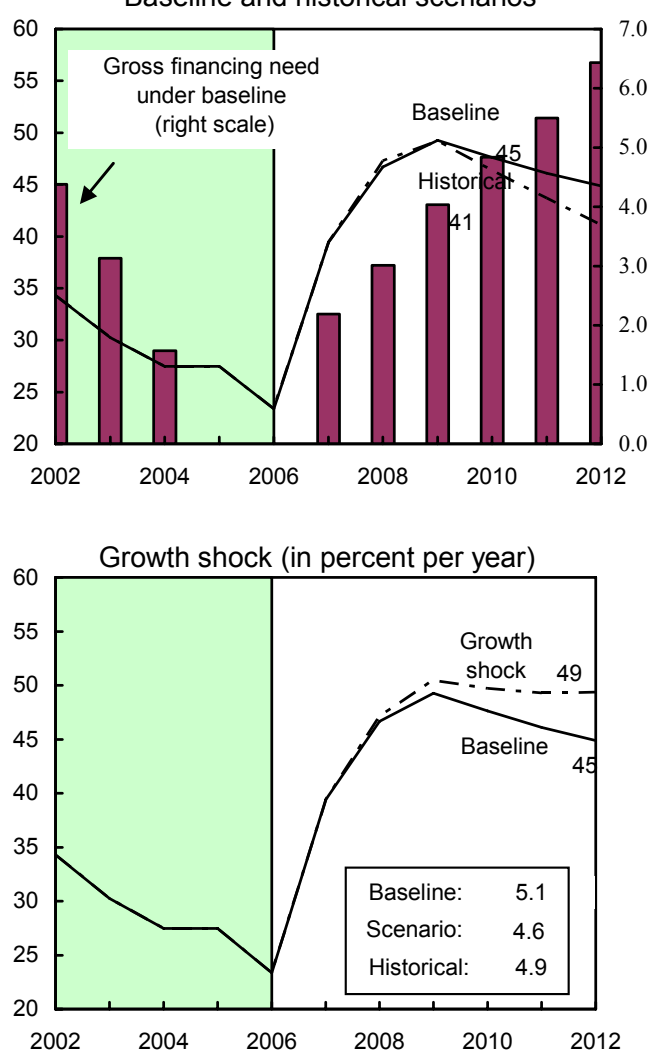

Combined shock 2/

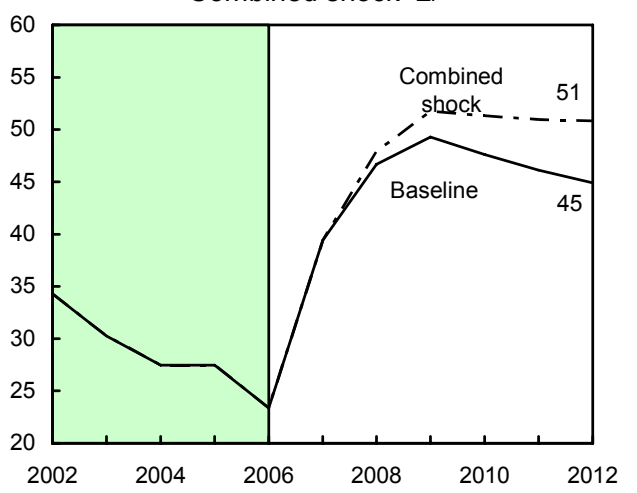

Interest rate shock (in percent)

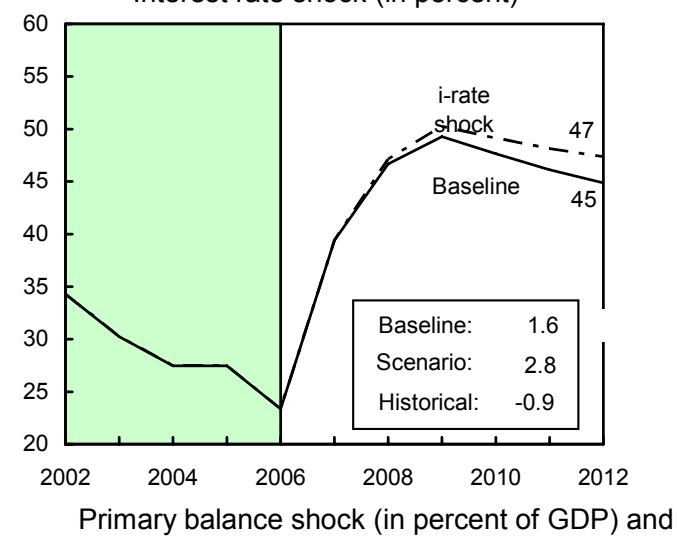

no policy change scenario (constant primary balance)

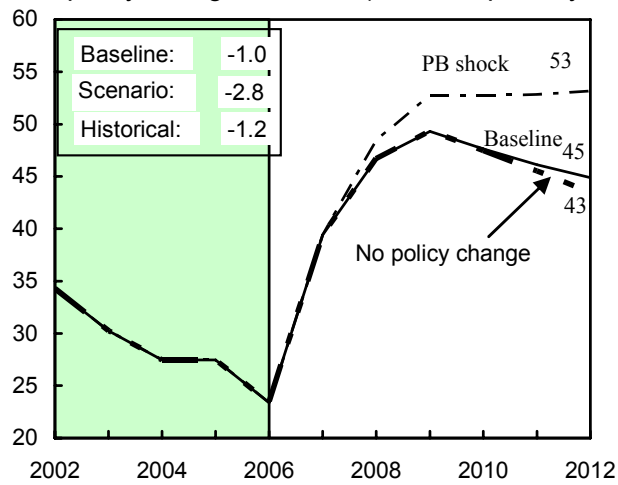

Real depreciation and contingent liabilities shocks $3 /$

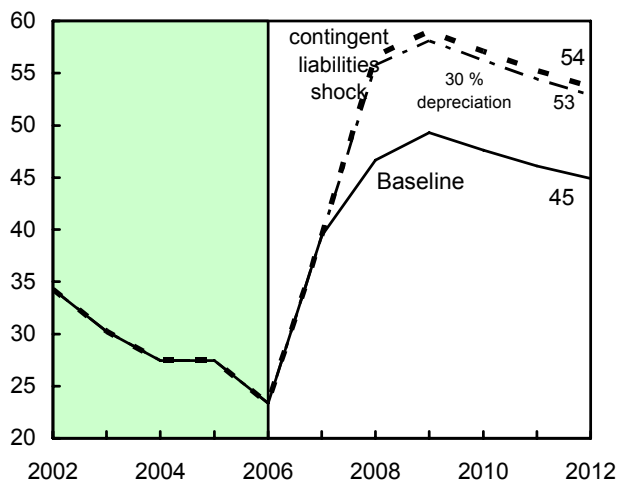

Sources: International Monetary Fund, country desk data, and staff estimates

$1 /$ Shaded areas represent actual data. Individual shocks are permanent one-half standard deviation shocks. Figures in the boxes represent average projections for the respective variables in the baseline and scenario being presented. Ten-year historical average for the variable is also shown.

2/ Permanent $1 / 4$ standard deviation shocks applied to real interest rate, growth rate, and primary balance. 3/ One-time real depreciation of 30 percent and 10 percent of GDP shock to contingent liabilities occur in 2008, with real depreciation defined as nominal depreciation (measured by percentage fall in dollar value of local currency) minus domestic inflation (based on GDP deflator). 


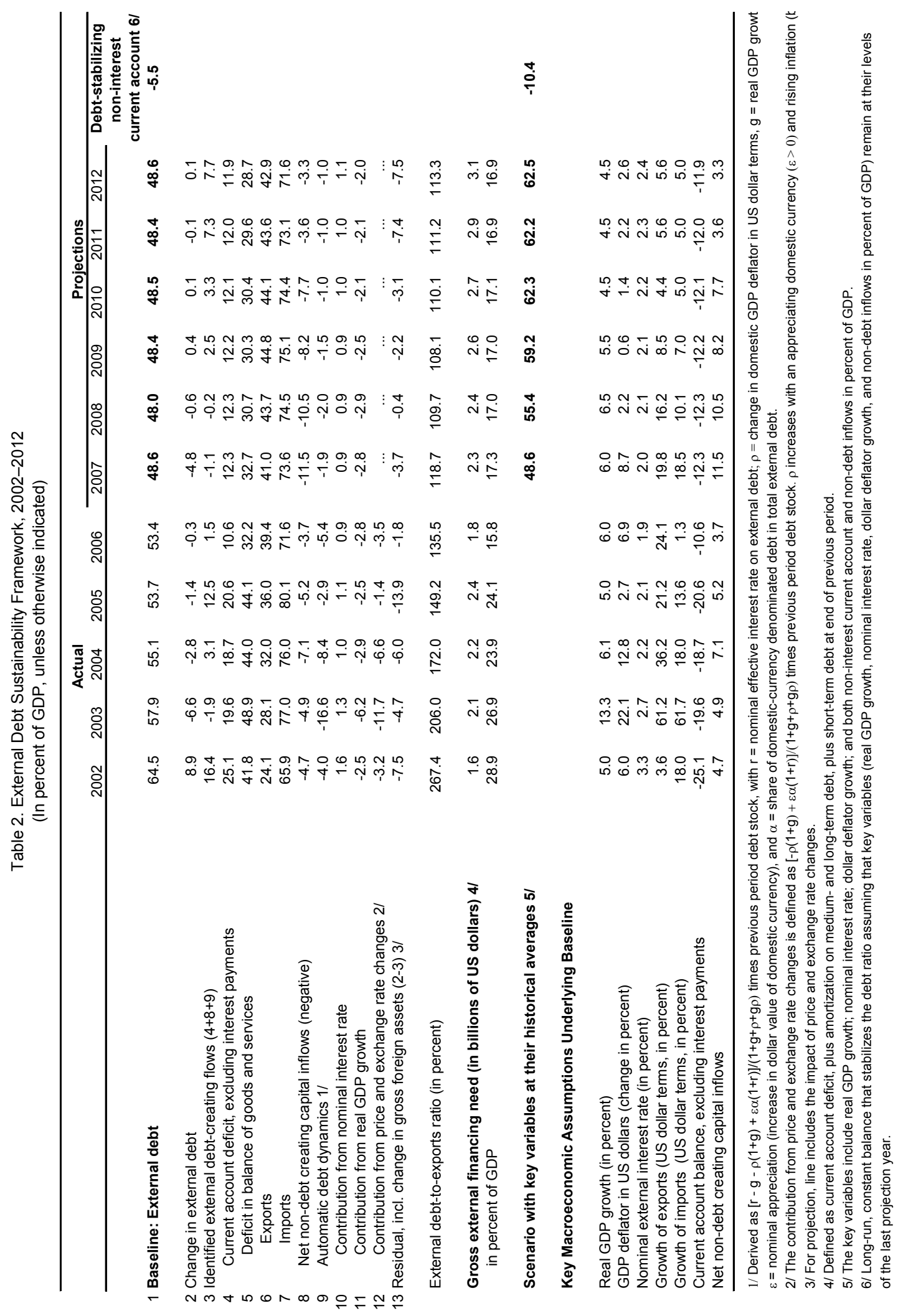


Figure 2. External Debt Sustainability: Bound Tests 1/ (External debt in percent of GDP)
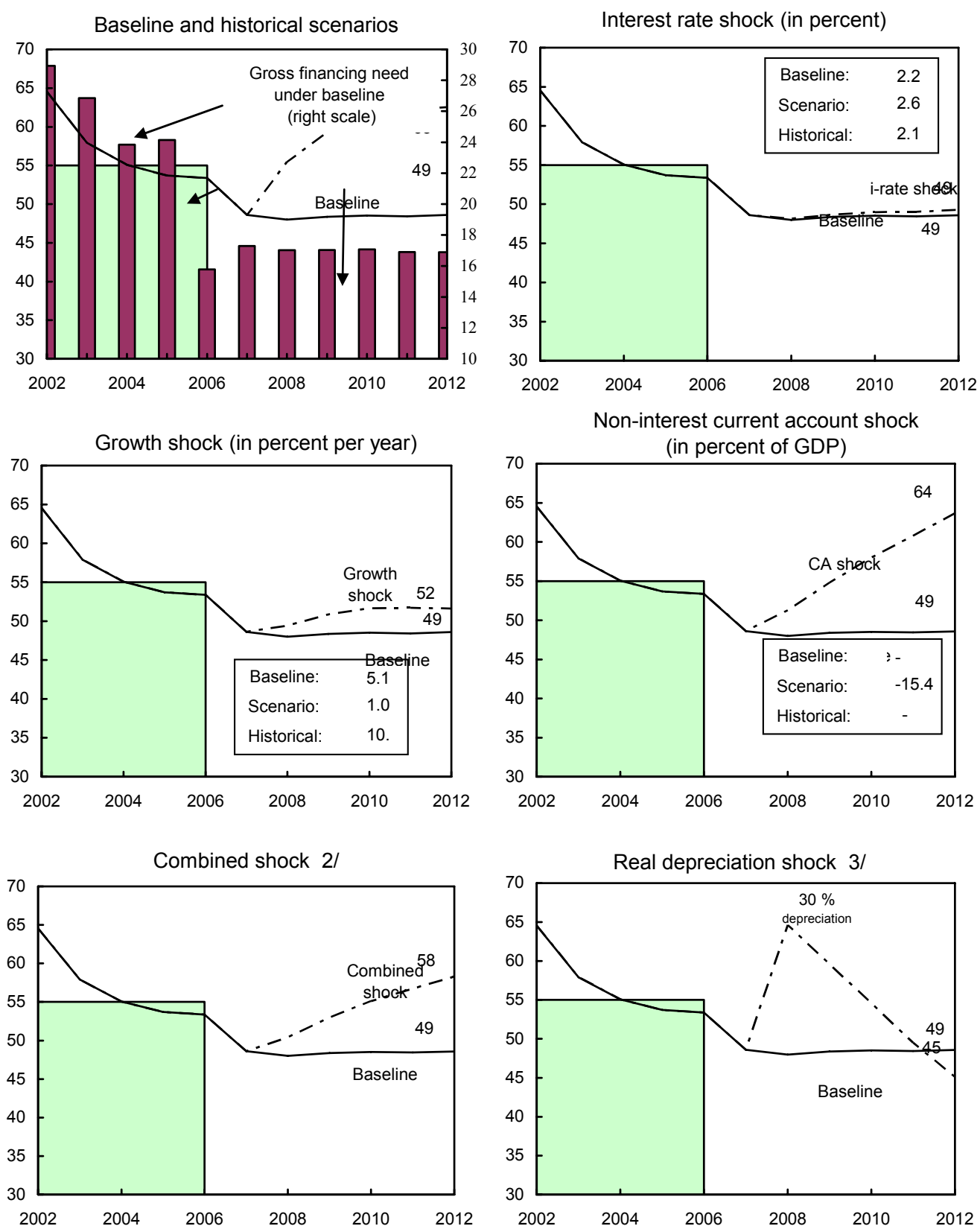

Sources: International Monetary Fund, Country desk data, and staff estimates.

1/ Shaded areas represent actual data. Individual shocks are permanent one-half standard deviation shocks. Figures in the boxes represent average projections for the respective variables in the baseline and scenario being presented. Ten-year historical average for the variable is also shown.

2/ Permanent $1 / 4$ standard deviation shocks applied to real interest rate, growth rate, and current account balance.

3/ One-time real depreciation of 30 percent occurs in 2008. 


\section{ANNEX I-BOSNIA ANd HERZEgovina-Fund RELATIONS}

(As of May 31, 2007)

Mission: Sarajevo, Banja Luka, May 9-22, 2007. The concluding statement of the mission is available at IMF statement on the Conclusion of the Article IV Discussions with Bosnia and Herzegovina.

Staff team: Messrs. Demekas (head), Cuc and Ms. Chivakul (all EUR), Mr. Maliszewski and Ms. Eble (FAD), and Mr. Jahjah (PDR), assisted by Mr. Slack, Resident Representative, and Mmes. Jankulov and Milić at the Resident Representative Office.

Country interlocutors: The mission met Mr. Spirić, Chairman of the State Council of Ministers; Mr. Vrankić, State Finance Minister; Mr. Branković, Prime Minister and Mr. Bevanada, Finance Minister of the Federation; Mr. Dodik, Prime Minister, and Mr. Džombić, Finance Minister of the RS, Mr. Kozarić, Governor of the CBBH, Dr. Schwarz-Schilling, High Representative, and Mr. Gregorian, Principal Deputy High Representative; and other representatives of the international community, political parties, employers and labor unions, and the media. Mr. Klein (OED) also participated in some of the meetings.

Data: Data provision is inadequate for surveillance purposes, especially in the areas of national accounts and balance of payments statistics, as well as fiscal statistics for local government.

I. Membership Status: Member since 12/14/1992; Article XIV

II. General Resources Account:

Quota

Fund Holdings of Currency

III. SDR Department:

Net cumulative allocation

Holdings

IV. Outstanding Purchases and Loans:

Stand-by-Arrangements

V. Latest Financial Arrangements:

$\begin{array}{ll}\text { Type } & \begin{array}{c}\text { Approval } \\ \text { Date }\end{array} \\ \text { Stand-by } & 8 / 02 / 2002 \\ \text { Stand-by } & 5 / 29 / 1998\end{array}$

Expiration

Date

$2 / 29 / 2004$

$5 / 29 / 2001$ $\underline{\text { SDR Million }}$

169.10

176.60

$\underline{\text { SDR Million }}$

20.48

0.12

$\underline{\text { SDR Million }}$

7.50

Amount Approved (SDR Million)

67.60

94.42
\%Quota

100.00

104.44

\%Allocation

100.00

0.61

\%Quota

4.44 
VI. Projected Payments to Fund on Expectations Basis:(SDR Million; based on existing use of resources and present holdings of SDRs):

\begin{tabular}{lrrrrr} 
& \multicolumn{5}{c}{ Forthcoming } \\
\cline { 2 - 6 } & 2007 & $\underline{2008}$ & $\underline{2009}$ & $\underline{2010}$ & $\underline{2011}$ \\
Principal & 6.00 & 1.50 & & & \\
Charges/Interest & $\underline{0.57}$ & $\underline{0.90}$ & $\underline{0.87}$ & $\underline{0.87}$ & $\underline{0.87}$ \\
Total & $\underline{6.57}$ & $\underline{\underline{2.40}}$ & $\underline{0.87}$ & $\underline{0.87}$ & $\underline{0.87}$
\end{tabular}

\section{Safeguards Assessment}

Under the Fund's safeguards assessment policy, Central Bank of Bosnia and Herzegovina (CBBH) was subject to an assessment in the context of a potential successor for the 2002 arrangement. The assessment was completed on January 24 , 2005 and recommendations were made to address weaknesses identified in the Bank's safeguards. Based on the information received from the authorities all the recommendations have been implemented.

\section{Exchange Rate Arrangements}

The currency of Bosnia and Herzegovina is the convertible marka (KM), introduced on August 11, 1997. On September 5, 2002, the State parliament approved an amendment to the CBBH law that changes the peg of the KM from the $\mathrm{DM}$ to the Euro under a currency board arrangement. The KM is pegged to the euro at $\mathrm{KM} 1=0.5113$ euro.

Bosnia and Herzegovina maintains restrictions on payments and transfers for current international transactions resulting from measures taken with respect to frozen foreign currency deposits as identified in IMF Country Report No. 02/52.

\section{FSAP}

Two FSAP missions took place in December 2005 and March 2006, and an Aide Mémoire was presented to the authorities. The FSAP assessed risks to financial stability and weaknesses in banking supervision using a Basel Core Principles assessment. It also considers financial sector development needs in the areas of insurance, access to finance, the insolvency regime and corporate governance, drawing on a detailed assessment of the OECD Principles of Good Corporate Governance. The FSSA was presented to the Board along with the 2006 Article IV consultation IMF Country Report No. 06/403.

\section{Last Article IV Consultation}

Bosnia and Herzegovina is on the twelve month cycle, subject to the provisions of the decision on consultation cycles approved on July 15, 2002. The last Article IV consultation was concluded on October 13, 2006. 


\section{Resident Representative}

Mr. Graham Slack has been the Fund's resident representative in Bosnia and Herzegovina since August 2004.

XII. Technical Assistance 2000-07

Department

FAD

$\mathrm{MCM}$

STA
Timing

August 2000

September-October 2000

July 2001

April 2002

April 2002

February 2003

May 2003

June 2004

March 2005

March 2005-2006

September 2000

March-April 2001

January-February 2002

October-November 2002

August-September 2003

September 2003

April 2004

January 2005

January 2005

April 2005

September 2005

November-December 2005

March 2006

November 2006

October 2000

December 2001

April-May 2004

May 2004

March 2005

November 2005-07

March 2007

\section{Purpose}

Treasury systems

Value-added tax

Treasury Systems

Value-added Tax

Treasury systems

Treasury systems

Public expenditure management

VAT policy and implementation

Poverty and social impact analysis

(VAT)

Macro-Fiscal advisor

Advisor on payments system.

Payments system, currency management, accounting and research

Payment system

Strengthening Banking Supervision

Banking supervision

International reserve management

AML/CFT Supervision

Advisor to CBBH Governor

Banking supervision

Credit Risk and Rapid Credit Growth

Financial soundness indicators

FSAP (primary mission)

FSAP (second mission)

Financial sector surveillance, banking supervision and reserve management

Money and banking statistics

Money and banking statistics

Money and banking statistics

Government finance statistics

Workers' remittances

Real sector statistics advisor

Data ROSC 


\section{Annex II-Bosnia \& Herzegovina: World Bank Relations}

\section{A. Bosnia and Herzegovina's Poverty Reduction Strategy}

1. The World Bank has taken the lead in supporting the structural and institutional reforms underpinning progress from post-conflict recovery, and the preparation of the Medium-Term Development Strategy/Poverty Reduction Strategy Paper (PRSP). The PRSP, drawing on the EC's 2003 feasibility study of the stabilization and association process, was agreed by entity and state governments in February 2004 for the period through 2007. The Paper commits the authorities to sustainable and balanced economic development, poverty reduction, and accelerated EU integration. The PRSP was updated in mid-2006 to reflect progress until that date.

2. Close to the completion of the PRSP, a number of the proposed measures have been implemented. Policy hesitancy, however, has delayed the implementation of some of the most important measures, including adoption of a law on higher education, a legal framework to establish minimum social entitlements for all citizens, introduction of targeted safety nets, and definition of reform of the pension system. Progress in reducing poverty and advancing privatization has lagged. The authorities intend to follow the PRSP with strategies for national development and social inclusion that will be the basis for the country's first National Development Plan (2008-13).

\section{B. World Bank Projects}

3. A Country Assistance Strategy (CAS) covering FY05-07 was approved in August 2004. It is anchored in the PRSP and structured along three pillars: (i) improving public finance and strengthening institutions; (ii) promoting sustainable private-sector led growth; and (iii) investing in key social and economic infrastructure. The base case sets IDA allocations at US\$152 million and is conditional on satisfactory macroeconomic and reform performance. The CAS is designed to help improve creditworthiness, which should ultimately enable $\mathrm{BiH}$ to access a substantially larger pool of IBRD resources.

4. While no longer receiving the levels of financing following the 1995 Dayton Accord, $\mathrm{BiH}$ still enjoys exceptional access to concessional IDA financing despite income per capita well-above the IDA threshold. The active IDA portfolio includes 15 active projects (12 investment, one adjustment and one GEF grant) with a total commitment of US\$299 million, of which US\$178 million remain to be disbursed. A US\$290 million "Power 4" electricity sector modernization project became effective in April 2007. The Bank will provide US\$36 million, with other multilateral and bilateral donors providing the rest.

5. The investment side of the portfolio has performed well, with only a few problem projects. On the adjustment (development policy) side of the Bank portfolio, progress has been held back by weak government ownership over structural reforms. As a consequence, the Bank let lapse at the end of June 2006 the \$51 million Second Social Sector Adjustment Credit (SOSAC2) and at the end of August 2006 the undisbursed balance of $\$ 18.5$ million 
under the Privatization Technical Assistance Credit (PTAC). The Economic Management Structural Adjustment Credit (EMSAC), with an undisbursed second tranche of \$24 million, lapsed at the end of 2006 due to insufficient progress in enacting laws on higher education, internal audit and public wages. The Bank delivered the Public Expenditure and Institutional Review (PEIR) to the authorities in June 2006.

7. Improving the business environment with support from Bank's Business Environment Adjustment Credit (BAC) will be critical to strengthening growth and employment and encouraging investment. Although delayed, supporting legislation has now been passed in both entities and is in the final stage of implementation. Pending the (surveybased) verification of intended outcomes in business registration and inspection reforms, the conditions for disbursement of the final US\$ 24 million tranche are expected to be met in late 2007.

For contact: Ivailo Izvorski (iizvorski@worldbank.org) or Penny Williams (pwilliams@worldbank.org). 


\section{AnNeX III-Bosnia ANd Herzegovina: StatisticAl IsSUES}

1. Data provision is inadequate for surveillance purposes, especially in the areas of national accounts and balance of payments statistics. Also, source data for government finance statistics need improvement. The Dayton peace treaty, which ended the civil war, implicitly gave responsibility for statistical functions to the two Entities (The Federation of Bosnia \& Herzegovina and Republika Srpska (RS)). In August 1998, the State created its own statistical institute, the Bosnia \& Herzegovina Agency for Statistics (BHAS) with a view to compiling country-wide statistics in accordance with internationally accepted methodologies, consolidating data produced by the Entities' Statistical Institutes, and acting as the primary coordinating agency for contacts with international agencies. Significant technical assistance has been provided in recent years, mainly by the European Union. A Fund resident statistical advisor was assigned to the Central Bank of Bosnia \& Herzegovina (CBBH) in May 1999, to provide technical assistance in the development of all areas of macroeconomic statistics on the basis of the comprehensive review conducted in early 1998 by the Fund's Multisector Statistics mission and the recommendations of Fund missions in the areas of monetary and balance of payments statistics. A country page for Bosnia \& Herzegovina in International Finance Statistics (IFS) was introduced in July 2001. A STA resident real sector statistical adviser was appointed to Bosnia \& Herzegovina in November 2005. The data ROSC mission undertaken in March 2007 assessed the quality of the macroeconomic statistics.

\section{A. Real Sector}

2. Efforts have been made in both Entities to improve real sector statistics, but results have been mixed. The Federation and RS both have published nominal GDP estimates using the production approach based on international standards recommended by the 1993 SNA, since 1998 and 1999, respectively. The first experimental accounts of GDP estimates by expenditure components were recently finalized and presented to main users in a meeting held at the BHAS on May 18, 2007. These estimates are available for 2004 and 2005 at current prices. Estimates for 2005 were also prepared at 2004 prices. After a thorough review and some revisions of the data, these estimates are to be released to the public shortly. These estimates are about 14 percent higher than the official GDP figures, which are based on the production approach and published by the BHAS. The discrepancy will be significantly reduced once the new estimates are revised with the estimates of informal and non observed economy (to be released in July 2007). The estimation of GDP using expenditure components will enter a regular production cycle and estimates for 2006 will be release later this year. In the event, GDP estimates do not adequately capture activities in the informal and unobserved economy, short-term business and consumer surveys are not available, and a statistical register of enterprises does not exist.

3. Both statistical offices compile price indices using outdated methodologies, and consistent time series are not available. Industrial production indices are prepared in each Entity, but there is no index at the country level and consistent time series are not available. Labor statistics are the weakest area for both Institutes, and data on employment, unemployment, and wage rates are based on questionable methodologies. The weights used to compute the retail price index (RPI) are significantly outdated and quality adjustments are not routinely undertaken 


\section{B. Balance of Payments}

4. Trade data are published by the BHAS and balance of payments statistics by the Central Bank of Bosnia \& Herzegovina $(\mathrm{CBBH})$. The quality of the balance of payments data is generally poor, particularly the coverage of foreign grants, workers' remittances, income received by residents from working for international organizations in Bosnia \& Herzegovina and the spending by their nonresident staff, trade credit by suppliers, informal trade, and changes in foreign currency cash holdings. Significant progress has been made in improving merchandise trade by introducing the ASYCUDA processing system, integrating customs administration for the whole country, reorganizing the customs, and introducing a trade classification system. BHAS now produces export and import data from customs records, but needs to produce the data on a general trade basis and not on a special trade basis.

\section{Government Finance}

5. The CBBH compiles government finance statistics (GFS) in accordance with the definitions and concepts of the Government Finance Statistics Manual 2001. The 2007 data ROSC mission found that the institutional coverage of the GFS is broadly consistent with international guidelines, but not all stocks and flows are measured due to insufficient source data. In addition, the GFS does not include transactions related to projects directly financed by international donors. Because accrual accounting has not yet been fully introduced in all government institutions, transactions are recorded on a mixed accrual/cash basis. Data on the level of outstanding domestic debt are being developed. The periodicity and timelines of data on government operations and quarterly consolidated central government operations meet or exceed GDDS recommendations. External government debt is published quarterly. GFS data are broadly consistent with the balance of payments, but not with the national accounts or monetary and banking statistics.

6. Since 2005, the CBBH has reported GFS to STA for publication in the Government Finance Statistics Yearbook, covering central government operations starting with data for 2003. Higher frequency fiscal data are not yet reported for publication in the IFS.

\section{Monetary Accounts}

7. The CBBH reports monetary accounts to the Fund on a countrywide and Entity basis. In early 2003, it began reporting weighted average interest rates for bank deposits and loans. The IFS includes interest rate data since January 2002. From 1996 to 2004, several Fund missions assisted in establishing an integrated system for compiling countrywide monetary statistics compatible with Fund standards. The April/May 2004 mission reviewed institutional changes and accounting developments that had important implications for monetary statistics and assisted in revising and updating the compilation procedures. The mission recommended improvements in, the treatment of "passive accounts" on banks' balance sheets, banks' claims arising from "credit card debts," "euro-linked" loans in national currency, and government accounts. The $\mathrm{CBBH}$ has been working towards reporting monetary data to the Fund using the Standardized Report Forms developed by STA. 
TABLE OF COMMON INDICATORS REQUIRED FOR SURVEILLANCE AS OF JUNE 15, 2007

\begin{tabular}{|c|c|c|c|c|c|}
\hline & $\begin{array}{l}\text { Date of latest } \\
\text { observation }\end{array}$ & Date received & $\begin{array}{c}\text { Frequency } \\
\text { of } \\
\text { Data }^{6}\end{array}$ & $\begin{array}{l}\text { Frequency } \\
\text { of } \\
\text { Reporting }^{6}\end{array}$ & $\begin{array}{l}\text { Frequency of } \\
\text { publication }^{6}\end{array}$ \\
\hline Exchange Rates & $6 / 15 / 07$ & $6 / 15 / 07$ & $\mathrm{D}$ & $\mathrm{D}$ & $\mathrm{D}$ \\
\hline $\begin{array}{l}\text { International Reserve Assets and Reserve } \\
\text { Liabilities of the Monetary Authorities }{ }^{1}\end{array}$ & $05 / 2007$ & $06 / 2007$ & M & M & M \\
\hline Reserve/Base Money & $05 / 2007$ & $06 / 2007$ & M & M & M \\
\hline Broad Money & $05 / 2007$ & $06 / 2007$ & M & M & M \\
\hline Central Bank Balance Sheet & $05 / 2007$ & $06 / 2007$ & M & M & M \\
\hline $\begin{array}{l}\text { Consolidated Balance Sheet of the Banking } \\
\text { System }\end{array}$ & $05 / 2007$ & $06 / 2007$ & M & M & M \\
\hline Interest Rates ${ }^{2}$ & $05 / 2007$ & $06 / 2007$ & M & M & M \\
\hline Consumer Price Index & $05 / 2007$ & $06 / 2007$ & M & M & M \\
\hline $\begin{array}{l}\text { Revenue, Expenditure, Balance and } \\
\text { Composition of Financing }{ }^{3}-\text { General } \\
\text { Government }^{4}\end{array}$ & 2005 & $07 / 2006$ & A & A & A \\
\hline $\begin{array}{l}\text { Revenue, Expenditure, Balance and } \\
\text { Composition of Financing }{ }^{3}-\text { Central } \\
\text { Government }\end{array}$ & $12 / 2006$ & $03 / 2007$ & M & M & M \\
\hline $\begin{array}{l}\text { Stocks of Central Government and Central } \\
\text { Government-Guaranteed Debt }\end{array}$ & 2006 & $03 / 2007$ & $\mathrm{~A}$ & A & A \\
\hline External Current Account Balance & Q4 2006 & $03 / 2007$ & Q & Q & Q \\
\hline Exports and Imports of Goods and Services & Q4 2006 & $03 / 2007$ & Q & Q & Q \\
\hline GDP/GNP & 2005 & $07 / 2006$ & A & A & A \\
\hline Gross External Debt & 2006 & $03 / 2007$ & $\mathrm{~A}$ & A & $\mathrm{A}$ \\
\hline
\end{tabular}

${ }^{1}$ Includes reserve assets pledged or otherwise encumbered as well as net derivative positions.

${ }^{2}$ Both market-based and officially-determined, including discount rates, money market rates, rates on treasury bills, notes and bonds.

${ }^{3}$ Foreign, domestic bank, and domestic nonbank financing.

${ }^{4}$ The general government consists of the central government (budgetary funds, extra budgetary funds, and social security funds) and state and local governments.

${ }^{5}$ Including currency and maturity composition.

${ }^{6}$ Daily (D); Weekly (W); Monthly (M); Quarterly (Q); Annually (A);Irregular (I); Not Available (NA). 


\section{INTERNATIONAL MONETARY FUND}

EXTERNAL

Public Information Notice (PIN) No. 07/85 FOR IMMEDIATE RELEASE July 24, 2007
International Monetary Fund $70019^{\text {th }}$ Street, NW

Washington, D. C. 20431 USA

\section{IMF Executive Board Concludes 2007 Article IV Consultation with Bosnia and Herzegovina}

On July 16, 2007, the Executive Board of the International Monetary Fund (IMF) concluded the Article IV consultation with Bosnia and Herzegovina. ${ }^{3}$

\section{Background}

Bosnia and Herzegovina labors under a complex political system, which causes fragmentation and duplication of many domestic policy functions, and weakens incentives for cooperation between the Entities and the State. A modest first-round attempt at constitutional reform failed in 2006; key measures, like police reform-a condition for signing the Stabilization and Association Agreement with the EU-are stalled; and policy coordination is weak.

The economy is nevertheless enjoying its fourth consecutive year of stable growth underpinned by the currency board. Export growth of 29 percent on the back of productivity gains, export price increases, and improvements in reporting following the introduction of the VAT, combined with robust domestic demand, pushed real GDP up 6 percent in 2006. The currency board anchored prices: headline inflation, reflecting the VAT effect and administered price hikes, averaged 7 percent last year but declined to $1 \frac{1}{2}$ percent in early 2007. The recorded current account deficit was almost halved last year to 11.5 percent of

\footnotetext{
${ }^{3}$ Under Article IV of the IMF's Articles of Agreement, the IMF holds bilateral discussions with members, usually every year. A staff team visits the country, collects economic and financial information, and discusses with officials the country's economic developments and policies. On return to headquarters, the staff prepares a report, which forms the basis for discussion by the Executive Board. At the conclusion of the discussion, the Managing Director, as Chairman of the Board, summarizes the views of Executive Directors, and this summary is transmitted to the country's authorities.
} 
GDP reflecting the improvement in the trade gap. Bank borrowing and other unidentified inflows pushed official reserves to $€ 2.9$ billion (51/4 months of imports) at end-April 2007.

The pace of financial deepening, a key contributor to growth, is consistent with regional trends, although supervision has weaknesses. After an initial surge, steady private sector credit growth of about 25 percent annually has financed activity and contributed to a gradual increase in the credit-to-GDP ratio. On the supply side, credit expansion is stimulated by competition and consolidation in the banking sector, which is dominated by foreign banks, and financed largely by lending from these banks to their local affiliates. Although bank soundness indicators are good and improving, a number of weaknesses remain in supervision, notably its fragmentation into two Entity-based agencies. While this has not been addressed, the inclusion of individuals in the credit registry in 2007, was a key step toward better risk management.

Fiscal policy has thus far been prudent and public debt low, though the size of the government is large. The VAT introduced on January 1, 2006 generated a surge of revenue, partly due to one-off factors, while the share of expenditures was kept at its 2005 level. The general government thus recorded a surplus of 3 percent of GDP in 2006. At about 50 percent of GDP, the size of the government is large, reflecting inefficiencies and duplication of functions. At the same time, at 23 percent of GDP at end-2006, public debt is low. Even after the planned bond issuance to cover outstanding domestic claims against the government-projected to raise the debt-to-GDP ratio by some 25 percentage points over the next three years - the debt will still be low in net present value terms, as most of it is concessional. The introduction of statutory borrowing ceilings for all levels of government was a major step toward fiscal discipline: though not yet binding, these ceilings could be effective in limiting fiscal deficits in the future.

This good overall picture reflects a benign external environment and the effects of past economic reforms. Growth in Bosnia and Herzegovina's trading partners was strong. World prices of metals-a key export-rose 55 percent in 2005-06. Low world interest rates facilitated the financing of the current account deficit. Although Bosnia and Herzegovina generally lags behind the region in terms of structural reforms, certain reforms in specific sectors have had a sizeable impact: industrial production and exports of key products, such as steel and aluminium, benefited from foreign investment; the successful introduction and administration of the VAT led to the good fiscal outcome in 2006; last but not least, the process of financial deepening was spurred by the privatization and opening of domestic banks to foreign participation.

\section{Executive Board Assessment}

Executive Directors welcomed the continued strong growth with low inflation, and the recent marked improvement in the external balance in Bosnia and Herzegovina, which they attributed largely to the effects of past structural reforms in key sectors and the benign international environment, as well as to the benefits of the currency board. 
Directors considered that the good economic performance offers an opportunity to tackle long-standing distortions that currently limit the economy's long-term growth potential: the large and inefficient public sector, segmented labor market, and overregulated business environment. While recognizing the institutional complexity for policy making, Directors underscored the need for far-reaching additional reforms. In particular, they encouraged the authorities to improve policy coordination, take steps to put the fiscal position on a sustainable path, strengthen financial stability, and accelerate structural reforms to sustain competitiveness and facilitate private sector development.

Directors expressed concern about the prospects of fiscal deterioration in 2007. They encouraged the authorities to adhere to the original budget spending plans in the Republika Srpska (RS) and to generate savings in the Federation's central government budget in order to offset the deficits likely to arise in the cantons. From a longer-term perspective, Directors welcomed the adoption of the statutory borrowing limits, but cautioned that they would not be sufficient to ensure medium-term sustainability. They stressed that a comprehensive medium-term policy framework is needed, targeting an overall general government balance, in light of the requirements of the currency board and uncertainties regarding the size of government liabilities. In this context, Directors stressed the importance of ensuring that domestic claims against the government, including for financial restitution, are kept at fiscally sustainable levels, and that private-public partnerships are used only once an appropriate institutional framework has been put in place.

Directors welcomed the progress in privatization, noting that the large expected receipts could help finance one-off priority expenses. They endorsed the RS plans to use privatization receipts for pension reform, but several Directors cautioned against financing private business development in strategic sectors.

Directors underscored the importance of improving fiscal policy coordination. They welcomed the authorities' intention to establish a firm legal basis for the Fiscal Council, and recommended that the current draft expand the definition of the general government to cover all public investment and strengthen penalties for noncompliance. Directors emphasized that effective coordination and good fiscal outcomes will not be possible without the political will to cooperate.

Directors noted that recent export trends are reassuring about Bosnia \& Herzegovina's external competitiveness position. At the same time, the external balance is dependent on performance of a few key sectors and vulnerable to commodity price shifts. To sustain these export trends, diversify the export base, and safeguard external competitiveness and the viability of the currency board, Directors encouraged the authorities to accelerate structural reforms. In particular, they called for actions to restructure the corporate sector, improve the business environment, make the country more attractive for foreign investment, and deregulate the labor market. Advancing internal integration will require harmonizing corporate income taxation and the system of social contributions, and ensuring portability of pension and health benefits and facilitating labor mobility. 
Directors noted that financial sector indicators have remained largely positive. They considered that maintaining financial stability in the presence of rapid credit growth requires further improving credit risk management, closing gaps in nonbank oversight, and unifying bank supervision. Directors favored tightening loan loss classification, raising penalties for noncompliance, and relaxing maturity matching requirements as a way to boost system soundness and weaken the link between credit expansion and foreign borrowing.

Directors welcomed the recent progress in improving national accounts statistics achieved with the help of Fund technical assistance, but noted that major problems remain in the timeliness and coverage of general government statistics and quality of balance-ofpayments estimates. Directors encouraged the authorities to step up their efforts to improve data quality, including by leveraging technical assistance from donors and following up on their recommendations.

Public Information Notices (PINs) form part of the IMF's efforts to promote transparency of the IMF's views and analysis of economic developments and policies. With the consent of the country (or countries) concerned, PINs are issued after Executive Board discussions of Article IV consultations with member countries, of its surveillance of developments at the regional level, of post-program monitoring, and of ex post assessments of member countries with longer-term program engagements. PINs are also issued after Executive Board discussions of general policy matters, unless otherwise decided by the Executive Board in a particular case. 
Bosnia and Herzegovina: Selected Economic Indicators, 2003-07

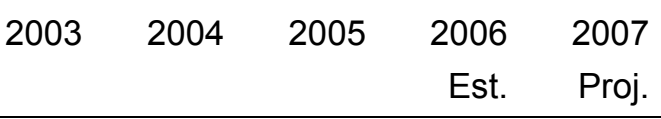

(Percent change)

Real GDP

CPI (period average) 1/

Money and credit (end of period)

Broad money

Domestic credit

Of which: credit to the private sector

General government budget

Revenue

Expenditure (on a commitment basis)

Overall balance

External public debt

NPV of external public debt

Total public debt

Balance of payments

Exports of goods and services

Imports of goods and services

Current account balance

(In percent of GDP)

Gross official reserves

(In months of imports)

External debt service

(In percent of exports of goods and services)

$\begin{array}{lllll}3.5 & 6.1 & 5.0 & 6.0 & 6.0 \\ 0.5 & 0.3 & 3.6 & 7.5 & 2.5\end{array}$

$\begin{array}{lllll}10.0 & 24.3 & 18.2 & 24.7 & 21.0 \\ 25.4 & 31.1 & 27.7 & 20.6 & 22.0 \\ 24.8 & 27.5 & 27.5 & 23.3 & 25.5\end{array}$

(In percent of GDP)

$\begin{array}{rrrrr}50.4 & 47.5 & 48.8 & 50.6 & 49.0 \\ 52.2 & 48.1 & 47.8 & 47.6 & 50.4 \\ -1.8 & -0.5 & 1.0 & 3.0 & -1.4 \\ 30.2 & 27.5 & 27.5 & 22.9 & 20.5 \\ 23.1 & 21.0 & 21.0 & 17.5 & 15.7 \\ 30.6 & 27.5 & 27.5 & 23.4 & 39.4\end{array}$

(In millions of euros)

$\begin{array}{rrrrr}1,939 & 2,402 & 2,905 & 3,575 & 4,134 \\ 5,313 & 5,704 & 6,465 & 6,495 & 7,431 \\ -1,439 & -1,482 & -1,750 & -1,044 & -1,357 \\ -20.9 & -19.7 & -21.7 & -11.5 & -13.4 \\ 1,422 & 1,768 & 2,145 & 2,761 & 3,254 \\ 3.2 & 3.7 & 4.0 & 5.1 & 5.3 \\ 289.4 & 364.0 & 234.1 & 318.9 & 322.0 \\ 14.9 & 15.2 & 8.1 & 8.9 & 7.8\end{array}$

Exchange rate regime

Currency board since August 1997

Exchange rate, July 16, 2007

$1 \mathrm{KM}=$ Euro 0.5113

Real effective exchange rate $(2000=100$, increase=appreciation)

$\begin{array}{llll}91.9 & 90.5 & 91.1 & 91.4\end{array}$ $\ldots 21$

Sources: Bosnian authorities; and IMF staff estimates and projections.

1/ Based on weighted averages for the Federation and Republika Srpska. In 2006, affected by the VAT introduction.

2/ Adjusted for VAT effects. 


\section{Statement by Agge Bakker, Executive Director for Bosnia and Herzegovina and Nir Klein, Senior Advisor to Executive Director July 16, 2007}

The authorities of Bosnia and Herzegovina $(\mathrm{BiH})$ thank the staff for the constructive and candid discussions in Sarajevo and Banja Luka. They share staff's appraisal on the challenges ahead and broadly agree with the report's key recommendations. As in previous years, the authorities give consent to the publication of the report.

\section{Macroeconomic developments and outlook}

Largely benefiting from favorable external conditions and past structural reforms, the $\mathrm{BiH}$ economy remained, in 2006, on a high growth path. Robust export performance, reflecting strong demand from trading partners, increased industrial production and high metal prices, contributed to a sharp decline in the current account deficit, and together with further accumulation of international reserves, mitigated external stability concerns. The higher-than-expected revenues, mainly attributed to the successful implementation of the VAT, and the noticeable fiscal discipline have led to a significant fiscal surplus and further reduction of public debt. In 2006, inflation has temporarily increased following the introduction of the VAT and several administered price hikes; however, with the currency board providing a credible nominal anchor, price growth significantly decelerated toward the year-end and subsequent months.

In the first half of 2007, most of the macroeconomic indicators have continued their positive trends. Export growth - although somewhat decelerated - remained strong, and together with a buoyant level of investment in the private and the public sectors, is expected to keep growth momentum at a high level. At this juncture, the authorities share staff's projection that the economic activity is about to expand this year at a magnitude of 6 percent. Owing to the deceleration of exports and renewed expansion of imports, the current account deficit is projected to slightly widen this year. Nevertheless, the financial account is expected to demonstrate great vigor as foreign direct investment is expected to triple its 2006 level mainly due to large-scale privatizations. ${ }^{1}$ On the fiscal side, in light of the increasing spending (partly as a result of planned investment and the settlement of domestic claims), the fading one-off effects of VAT introduction and declining international assistance, the authorities project a limited fiscal relaxation.

As for the medium term, the authorities are in broad agreement with staff that external conditions are likely to remain comfortable thus supporting domestic economic activity. Yet, in view of the risks arising from the high external deficit and the increasing spending needs, they acknowledge that greater efforts are required to keep the economy on a solid path of growth and development. In this context, the authorities intend to step up and accelerate the implementation of structural reforms with the aim of improving the

\footnotetext{
${ }^{1}$ In 2007, capital flows of foreign direct investment are projected to register a record-high level of 11.5 percent of GDP.
} 
cooperation between the two Entities, while strengthening the coordination among all government levels to facilitate consistent economic policies.

The authorities regret that the high growth rates were not reflected in significant reduction of unemployment and poverty. ${ }^{2}$ They appreciate staff's analysis on the labor market and broadly concur with its main message that a more flexible wage structure, greater labor mobility and appropriate training and education policies as well as more prudent labor law enforcement would be instrumental in reducing the currently high unemployment rate. The authorities are now reviewing the effectiveness of the current policies to promote employment, and with the assistance of the World Bank, they intend to prepare a National Development Plan for 2008-13, which will be a continuation of BiH's medium-term development strategy that runs until end-2007 and is part of the EU accession agenda.

\section{Structural reforms and trade liberalization}

The authorities agree with staff that preserving competitiveness is necessary to contain external vulnerabilities. Yet, they note that the lack of political support exacerbated by fragmented institutions have prevented them from more forcefully moving forward with important structural reforms and thus contributed to the BiH's low ranking among other countries in the region in several transition indicators. Now, with the new government in place, the authorities are prepared to accelerate reform momentum and boost competition and efficiency in the markets. In this context, they note that significant progress has been recorded this year with regard to the privatization process, particularly in Republika Srpska (RS), which completed the sale of RS telecom (the second largest telecom company in $\mathrm{BiH}$ ) and a large oil refinery. At the Federation, although limited progress has been achieved so far in this area, the authorities' privatization plan for this year is rather ambitious and envisages the sale of some of the entity's most profitable companies. These include the engineering firm Energoinvest, the construction company Hidrogradnja and the aluminum smelter Aluminij Mostar, BiH's largest exporter. The authorities underline their intention to use the large proceeds from privatization to finance new investment projects, which they consider necessary given the poor infrastructure condition.

As part of the strategy to develop the private sector, the authorities have also progressed with reforms aimed at enhancing the business climate. In this regard, they recently introduced a new countrywide system of business registration while business inspections have been streamlined and consolidated. ${ }^{3}$ Moreover, the Anti-trust council is now fully functional and EU-styled legislation is being enforced for all new mergers and market entry.

Bosnia and Herzegovina remains committed to trade liberalization. In late 2006, $\mathrm{BiH}$, along with four other countries in the region, agreed to join an expanded Central European Free-Trade Agreement (CEFTA). While the agreement still needs to be ratified by the

\footnotetext{
${ }^{2}$ The poverty rate has declined from 19.5 percent in 2001 to 17.8 percent in 2004 .

${ }^{3} 38$ percent of business regulations have been changed in the RS (while 32 percent were completely abolished). The Federation will undertake similar revision of business-related regulations.
} 
parliament (end of July), the authorities expect that it will boost import demand in several of BiH's key regional export markets.

\section{Fiscal issues}

In 2006, the authorities continued to implement prudent fiscal policy. Despite early concerns regarding the transition of the tax system, they note with satisfaction that the VAT implementation was successful as it generated significant revenues, well above previous projections. This, together with a moderate decline in expenditures (as a share of GDP), led to a considerable fiscal surplus of 3 percent of GDP, in the face of a continuous decline in the international financial assistance, and also contributed to the improvement of BiH's credit rating. Looking ahead, the $\mathrm{BiH}$ authorities underline their intention to continue with fiscal consolidation. They recognize that the public sector is large and inefficient and thus needs to be reduced, yet in view of the increasing spending needs, inter alia due to EU integration and significant domestic claims, they see merit in gradual adjustment.

The authorities perceive staff's medium-term fiscal projections, which rely on the assumption that policies remain un-changed, as overly pessimistic. They recognize that part of the strong fiscal performance last year stemmed from one-off effects, however they are confident that the acceleration of privatization, the projected strong economic growth and their efforts to reduce the informal sector, will support the continuation of robust revenue growth and therefore compensate for the increasing spending needs. According to their view, the 2007 fiscal stance will indeed demonstrate some relaxation (compared to 2006); however, it is deemed possible that the fiscal budget will still record a surplus.

As part of their efforts to streamline the public sector and contain expenditures, the authorities have established a working group to review the wage structure at the public sector with a view of finalizing the draft law and adopting it by the year-end. Moreover, the authorities plan to consolidate the various laws on demobilized soldiers in order to abolish duplicate benefits claims. The authorities are also confident that the adoption of the government debt laws, which was already adopted by the State and RS and is pending for approval at the Federation, would provide a firm framework that would ensure fiscal consolidation over time.

Following a successful implementation of the VAT system, the authorities plan to reform the direct tax system with a view of harmonizing and simplifying the tax schemes in both Entities. In this regard, considerable progress has been made in RS in 2006 with the adoption of the Law on Personal Income Tax and the Law on Corporate Income Tax and it is expected that similar legislation will be adopted in the Federation this year. The authorities recognize that such reform, which also envisages tax rate cuts in the Federation, would be beneficial to promote job creation and to reduce the currently significant informal sector in the economy. Therefore, they do not expect that it will have an adverse effect on the overall revenue collection. 
The authorities recognize the necessity to improve coordination to enhance the fiscal position. In the absence of a legislative framework for the work of the National Fiscal Council (NFC), a Budget Coordination Board (BCB) was formed, ${ }^{4}$ and it held regular meetings throughout the process of preparation of the Budget Framework Papers for 2008-10 for the State and the Entities. The BCB agreed on a harmonized budget calendar for all government levels and work is underway to harmonize the appropriate legal provisions. Further improvement in the process of budget preparation will be achieved with the adoption of the NFC law. In this regard, the authorities have prepared a draft of the NFC law and intend to submit this to the parliament for its approval shortly. They realize that this is a first step to improve fiscal coordination.

\section{Monetary policy}

In 2006, the dynamics of prices were largely affected by the VAT introduction at the beginning of the year and certain hikes in administrative prices of electricity, gas and public utilities in the Federation. Consequently, inflation accelerated in the first three quarters and was accompanied by a sharp increase in nominal wage. However, with the currency board providing a credible nominal anchor to the economy, the adjustment process to the new price environment gradually diminished, and toward the end of the year price growth started to decelerate. This trend continued in the first half of 2007 when the inflation rate reverted to low levels of 1-2 percent in both Entities. At this juncture the Central Bank of Bosnia and Herzegovina $(\mathrm{CBBH})$ does not expect to change the reserve requirement (its main monetary instrument), however it will continue to closely monitor market developments and will adjust its policy instruments if needed.

The CBBH is confident that the observed high credit growth mainly reflects the ongoing process of financial deepening and expects the steady expansion of credit to remain significant, in line with regional trends, and without undermining financial stability. The CBBH also notes that the inclusion, in 2007, of households and companies in the credit registry would significantly improve risk management of lending institutions.

\section{Financial stability issues}

While the $\mathrm{CBBH}$ views the current financial system as sound, with some financial indicators such as the Non-Performing Loans (NPL) and Return on Equity (RoE) showing continuous improvement, it continues to take measures to improve its oversight on the markets. In this regard, the $\mathrm{CBBH}$ established, in line with FSAP recommendations, a Financial Stability Unit within the central bank, which is expected to provide, through the issuance of financial stability reports, frequent assessments of the financial sector developments and potential risks. That said, the $\mathrm{CBBH}$ acknowledges that there is scope for ore policy actions to contain the remaining weaknesses. In this context, bank supervisors have already started working on more strict loan classification with the intention of introducing them in the next few months. The authorities support the FSAP recommendation that banking agencies should follow up to relax the maturity-matching requirement between a

\footnotetext{
${ }^{4}$ The Budget Coordination Board consists of assistant ministers for budget, directors of Macroeconomic Analysis Unit (MAU) and Directorate of Economic Planning (DEP) and the head of budget and finances in Brcko District.
} 
bank's assets and liabilities so as to improve banks' liquidity and thus weaken the link between credit expansion and foreign borrowing.

The authorities broadly concur that a single, independent, and effective bank supervisor at the state level, either at the $\mathrm{CBBH}$ or as a separate institution, would be more effective in safeguarding financial stability, with greater cross-border cooperation, and will be consistent with the general approach of creating single economic space in $\mathrm{BiH}$. Nevertheless, they underline that the decision on the final setup of bank supervision has significant political implications.

As part of the efforts to strengthen the economic and financial cooperation between the European Union and Bosnia and Herzegovina, the $\mathrm{CBBH}$ has signed early this year the Protocol of the Eurosystem Needs Assessment Programme with the European Central Bank and the European Commission to $\mathrm{BiH}$. The aim of the program is to assess the current functioning of the $\mathrm{CBBH}$ in various areas, including financial stability, statistics, internal audit and economic analysis and research, and eventually provide recommendations on the necessary reforms that are needed to match the $\mathrm{CBBH}$ operations with best practice of the EU central banks. While awaiting for the final solution on the bank supervision structure, it was also agreed that the assessment would include a comprehensive examination of the coordination of banking supervision with the Banking Agencies from both Entities with a view of improving the CBBH's activities in this domain.

\section{Statistics}

The authorities are cognizant that more remains to be done to improve the quality of statistics, particularly real sector statistics, government finances and the balance of payment. In this regard, they are making efforts to improve the coordination and cooperation between the statistics agencies of the Entities and the State to construct reliable data on an aggregate level. This step, together with the assistance of the Fund's statistics department, has recently allowed them to produce an assessment of GDP by expenditure approach. The authorities highly appreciate the Fund's assistance in this area and look forward to the completion of the data ROSC, which they intend to follow up on.

\section{Going forward....}

The authorities see the accession to the EU as the main political objective and attach enormous importance to the process. They have successfully completed the technical negotiations on the Stabilization and Association Agreement (December 2006) and the noticeable progress in reform implementation has made the $\mathrm{BiH}$ economy more compatible and integrated with the EU and the region. That said, the authorities acknowledge that there are significant challenges down the road, also in view of the closure of the Office of the High Representative (OHR) foreseen for next year. Thus, they see merit in the continuation of assistance from the international community and reiterate their intention to maintain close cooperation with the Fund in the years ahead. 